\title{
Determinants of Sustainable Food Consumption: A Meta-Analysis Using a Traditional and a Structura Equation Modelling Approach
}

\author{
Yan Han \\ Beijing Institute of Fashion Technology, Beijing, China \\ $\&$ \\ Faculty of Social Sciences, University of Stavanger \\ 4036 Stavanger, Norway \\ E-mail: xtoula@188.com
}

Håvard Hansen (Corresponding author)

UiS Business School, University of Stavanger, 4036 Stavanger, Norway

Tel: 47-971-58-768Ｅ-mail: havard.hansen@uis.no

Received: November 24, 2011

Accepted: December 13, $2011 \quad$ Published: March 1, 2012

doi:10.5539/ijps.v4n1p22

URL: http://dx.doi.org/10.5539/ijps.v4n1p22

\begin{abstract}
Based on a database of 16 empirical studies, this MASEM study aims to provide an overview of existing antecedents of sustainable food consumption within an integrative framework based on the TPB. Among the antecedents, Personal Norm, Attitude and Subjective Norm displayed strongest effects on Intention, followed by Beliefs, Perceived Behavioral Control and Ethical Concern, which were also within the scope of medium to large. As for the correlations of Behavior, Personal Norm, Attitude and Subjective Norm showed strongest effects, and the effects of Intention, Beliefs and Perceived Behavioral Control were also within the scope of medium to large. Results of the MASEM study indicate that both TPB and extended TPB models have statistically acceptable power in explaining the intention and behavior of sustainable food consumption, while a slight increase was made to the amount of explained variance of intention by adding Personal Norm to TPB. The results of our meta-analyses give readers an understanding of the magnitude and significance of relationships between antecedents and intention in the sustainable food consumption domain.
\end{abstract}

Keywords: Sustainable food, Organic food, Sustainable consumption, TPB, Meta-analysis, Meta-Analytic Structural Equation Modeling (MASEM)

\section{Introduction}

Reducing the impacts of all social actors' consumption practices is vital to achieve sustainable development (UNCED, 1992). The collective effects of individual consumers are undoubted. First, their consumption behavior has direct influences on the environmental sustainability, and second, their purchasing choice has indirect influences on the environment through affecting the manufacturing and marketing of commodities and services. Within the frame of agriculture, it indicates that organic farming contributes positively to good environmental soil condition, agro-biodiversity, and natural biodiversity, according to a meta-analysis of the differences in environmental impacts between organic and conventional farming (Mondelaers et al., 2009). The influence of conventional agricultural production on ecosystems and the importance being attached to the role of consumers in maintaining the global environmental sustainability have fueled many researchers to identify determinants of both intention and behavior of sustainable food consumption since the 1990s

In the relatively early stage, researchers mainly chose the values theory of Rokeach (1973) and Schwartz (1992) as the theoretical framework for studies on sustainable food consumption (Aertsens et al., 2009). More recently, researchers have also to applied the Theory of Planned Behavior (TPB) (Ajzen, 1985, 1988, 1991) as the 
conceptual model for explaining sustainable food consumption (e.g., Guido et al., 2010; Arvola et al., 2008; Dean et al., 2008; Chen, 2007; Thøgersen \& Ölander, 2006; Saba \& Messina, 2003; Bamberg, 2002).

The TPB, which deals with the information processing of the individual whose behavior is guided by rational decisions, is perhaps the most influential theory for predicting and explaining human behaviors (Armitage \& Conner, 2001). According to the TPB, the strongest and most proximal predictor of volitional behavior is one's behavioral intention, which is an indication of a person's readiness to perform a given behavior. As a general rule, the stronger the intention to engage in behavior, the more likely should be its implementation. The TPB further postulates three main factors which determine one's behavioral intention: attitude toward a behavior (AB), subjective norm (SN) and perceived behavioral control (PBC), with each predictor weighted for its importance in relation to the behavior and the population of interest. Attitude toward a behavior reflects the degree to which performance of the behavior is positively or negatively valued. Subjective norm is the perceived social pressure to engage or not to engage in a behavior. Perceived behavioral control refers to people's perceptions of their ability to perform a given behavior. According to the TPB, the more positive one's attitude and subjective norm, and the greater one's perceived behavioral control regarding a behavior, the more likely a person is to intend to perform that behavior. The latter construct, PBC, is not only a direct antecedent of intention as are attitudes and subjective norms, but also a determinant of behavior along intention in cases where performance of the behavior is less volitional. In practice, intention and PBC are often found to have main effects on behavior, but no significant interaction.

Several meta-analytic reviews support the success of the TPB in the prediction of behavior and attitude-behavior consistency for a wide range of human behaviors (e.g., Cooke \& French, 2008; Armitage \& Conner, 2001; Sheeran \& Taylor, 1999; Godin \& Kok, 1996) including pro-environmental behaviors (e.g., Gardner \& Abraham, 2008; Bamberg \& Möser, 2007). These meta-analyses have reported a considerable attitude-intention relationship, medium to large sized SN-intention, PBC-intention and intention-behavior relationships, and a small to medium sized PBC-behavior relationship. As for the explained variances, intention normally explained between 19 percent and 38 percent of the variance in future behavior. Attitudes together with SN accounted for 33 percent to 50 percent of the variance in intention. The explained variance in intention could be increased by 5 percent to 12 percent and the explained variance in behavior could be increased by 2 percent to 12 percent over and above intention by adding PBC into the model.

Despite considerable supports for the TPB constructs in predicting intention and behavior, it is also apparent that the TPB still leaves a substantial proportion of unexplained variance in intention and behavior. So other conceptual factors besides the TPB constructs should be considered. Even though Ajzen (1991) argued that any other variable external to the TPB model could have only an indirect effect on intention mediated by attitude, SN, or PBC, several studies on pro-environmental behavior have extended the TPB and successfully improved the explanatory power of the model. One of such additional factors that possess particular motivational power is personal norm (PN).

Personal norm, which is also called moral norm or perceived moral obligation, reflects the individual's perception of the moral correctness or incorrectness of performing a particular behavior (Ajzen, 1991) and, according to Ajzen, takes into account "personal feelings of . . . responsibility to perform, or refusal to perform, a certain behavior" (p. 199). Several studies on pro-environmental behavior have supported the significance of adding PN into the TPB model. For example, Harland, Staats, and Wilke (1999) reported that the explained variance of intention could be increased by 1 to 10 percent by adding personal norm into the model. Moreover, Thøgersen and Ölander, (2006) found a very strong relationship between PN and organic food purchasing behavior. Two meta-analyses in the pro-environmental behavior domain confirmed the contribution of PN in improving the explanatory power of the TPB (Bamberg and Moser, 2007) and reported a large-sized PN-intention relationship (Bamberg and Moser, 2007) and a medium to large sized PN-behavior relationship (Gardner \& Abraham, 2008; Bamberg and Moser, 2007).

\section{Sustainable Food Choice Motives}

Although food is a basic human need and eating is a daily undertaking, food choice is, however, such a complex function of multiple antecedents that several researchers have proposed different models to organize various food choice determinants (Köster, 2009; Pettinger et al., 2004; Prescott et al., 2002; Caplan et al., 1998; Furst et al., 1996). The food choice questionnaire (FCQ; Steptoe et al., 1995) provides an integrative framework involving nine motivational dimensions: health, mood, convenience, sensory appeal, natural content, price, weight control, familiarity, and ethical concern. It has been proposed that the effects of cultural, social, economic, psychological, and demographic factors on food choice may be mediated by one's attitude and beliefs (Shepherd \& Raats, 1996; 
Conner, 1993).

In a recent review of factors driving organic food consumption, Hughner et al. (2007) synthesized the results of relevant studies and classified these drivers into two broad categories. The first factor is consumers' purchasing motives, and relates to health and nutritional concern, superior taste, concern for the environment, food safety, lack of confidence in the conventional food industry, concern over animal welfare, support of local economy, more wholesome, nostalgia, and fashionable/curiosity. The second factor, hindrances to purchasing, consists of issues like high price premiums, lack of organic food availability, poor merchandising, skepticism of certification boards and organic labels, insufficient marketing, satisfaction with current food source, and sensory defects.

\section{The Present Study}

Hines et al. (1986/87) and Sebastian and Guido (2007) performed meta-analyses of psycho-social determinants of pro-environmental behavior, and both of these studies provide convincing syntheses and evidence for the utility of psycho-social variables as predictors of pro-environmental behavior. Both of the papers studied general pro-environmental behavior instead of any specific behavioral aspect. Admittedly, all pro-environmental behavioral items together are part of a person's lifestyle, so all of them are influenced by the person's psycho-social variables. However, there could be some differences between sustainable food consumption behavior and other pro-environmental behaviors, examples being both waste reduction or cycling to work. In fact, even within the relatively narrower domain of sustainable consumption, the same green consumers would not use the same information sources or decision-making criteria for products in different sectors, though some degrees of consistency in purchases within sectors have been identified (McDonald et al., 2009). Thus the present study attempts to perform a meta-analysis of psycho-social determinants of consumption behavior of sustainably produced food. To be specific, the purpose of this meta-analysis is twofold: First, it aims at synthesizing the results across studies and establishing the existence and magnitude of antecedents' influences on both intention and behavior of sustainable food consumption. Secondly, it combines meta-analytic techniques with structural equation modeling (SEM) to test the TPB model and the extended TPB (ETPB) model, which integrates personal norm into TPB, in the sustainable food consumption domain.

Besides PN and the constructs of TPB, three other factors which have been identified as important motives for sustainable food purchase, were included in the traditional meta-analysis part, namely Health Concern (e.g., Michaelidou \& Hassan, 2008; Tanner \& Kast, 2003), Ethical Concern (e.g., Chen, 2009; Honkanen et al., 2006), and Beliefs (e.g., Arvola et al., 2008; Robinson \& Smith, 2002). Health Concern refers to consumers' health consciousness and concerns about their state of well-being. Ethical Concern reflects consumers' ecological consciousness and concerns about sustainability in its widest sense. Beliefs here refer to beliefs about the environmental impact of food production practices.

In the meta-analytical structural equation modeling (MASEM) part, however, only the TPB and the ETPB models are tested and compared, due to the relative small number of included primary studies for the rest three constructs. The present study tries to compare the TPB with the ETPB in their powers of explaining the intention and behavior in the sustainable food domain. It is hypothesized that the ETPB is relatively superior to the TPB in explaining the intention and behavior of sustainable food consumption.

\section{Method}

\subsection{Literature Search}

In order to minimize the likelihood of excluding important relevant papers that could provide estimates of the relations among constructs in the proposed integrative model, an exhaustive literature search was conducted through three main strategies.

The first strategy consisted of searching for studies published up to February 2010 through computerized databases (Academic Search Elite, Business Source Elite, Emerald, ISI Web of Science, ScienceDirect, SocINDEX, Wiley InterScience, EconLit, PsycINFO, Business Source Premier, Springer). Toward completing a comprehensive, exhaustive literature search, a broad scope of terms were used in abstract search, with a multitude of variations of the search terms organic, food, product, consume, purchase, buy, alternative food, sustainable, conscious, eco-friendly, behavior, attitude, concern, environment, green, ecological, and ethical.

Considering the difficulty of identifying studies relevant to the research question by keyword searching alone, we manually searched 23 journals that had published, or seemed likely to publish, studies relevant to sustainable food consumption (e.g., Food Quality and Preference, Appetite, British Food Journal, Environment and Behavior, Journal of Environmental Psychology, etc.) from 1995 to the present. This restriction was based on the fact that the majority of relevant studies obtained from preliminary literature search were published after 1995. 
Third, we examined the reference lists of recent relevant meta-analytic and narrative review articles (e.g., Aertsens et al., 2009; Hughner et al., 2007; Bamberg \& Möser, 2007). References appearing in some other key papers were also searched for additional studies that might be included in the current meta-analysis. However, the search was restricted to published papers.

\subsection{Inclusion Criteria}

An article would be included in the present meta-analysis if it satisfied the following inclusion criteria:

(1) It was published in peer-reviewed English language journals.

(2) It was an empirical quantitative study exploring relationship between some antecedents and consumers' attitudes, intentions and/or behaviors toward organic food or sustainably produced food (genetically modified food are not included in the present review).

(3) At least two of the constructs included in our integrative model were analyzed in the article.

(4) The operational definitions as well as the reported items of the measurements in the article coincided with our constructs;

(5) Both bivariate Pearson correlations and sample size were reported.

Initially, hundreds of potentially suitable articles in the sustainable food domain were identified. Abstracts of these papers were sifted, and those that definitely did not meet the inclusion criteria were rejected (e.g., articles focusing on organic agriculture regulation, organic food network, or organic certification, etc.), leaving more than 100 papers that were related to sustainable food consumption. Abstracts of these papers were examined in greater detail. After closer inspection of the full papers, the majority of studies were rejected and only 17 articles satisfied all the above criteria and were retained.

In order to satisfy the independence of each study included in the meta-analysis, we ensured effect sizes acquired from one population (as determined by identical sample characteristics) were cited only once. For this reason, one study (Dean et al., 2008) was excluded because it was based on a sub-sample of another larger project (Arvola et al., 2008). If the same study design was carried out in multiple but independent samples (e.g., Arvola et al., 2008), results from those sub-samples were entered into the meta-analysis as independent samples (Hunter \& Schmidt, 1990, p. 451). One study (Saher et al, 2006) investigated participants' attitudes towards both genetically modified and organic food, and only correlations in the organic field were included. When a single study provided more than one effect size estimate for the same relationship (e.g., Bissonnette \& Contento, 2001, which focused on both organic food and locally grown food), the simple average values were recorded (Heneman, 1986). Finally, a total of 16 independent studies comprising of 19 samples were included in the present review, and 18 correlation matrices (only correlations in pooled data of two sub-samples were reported in one study (Guido et al., 2010)) provided the input for calculating the pooled average correlations.

\subsection{Coding and Features of Studies}

A pre-specified data extraction sheet was developed to record study features (e.g., authors, title, publication sources); methodological characteristics (e.g., research design, sampling method, variable definitions, psychometric properties of instruments); sample characteristics (e.g., sample country, participants, age range, proportion of female); and study findings (e.g., reliability of scales, correlation coefficient between two constructs, main findings in authors' words).

As mentioned before, samples from 16 studies, including one that assessed three independent samples (Arvola et al., 2008) fulfilled inclusion criteria. Therefore, the present meta-analyses were based on 18 independent correlation matrices and 11,571 participants (see Table 1).

The majority of these studies were carried out in Europe ( $\mathrm{k}=13,81.3 \%)$, followed by America $(\mathrm{k}=2,12.5 \%)$, and only one study (6.3\%) was conducted in Asia. Except for 4 studies (25\%) including young adults or students as respondents, all the other $12(75 \%)$ recruited participants from the general population. As for theoretical frameworks, the TPB or extended TPB still dominated $(\mathrm{k}=10,62.5 \%)$, even though some researchers chose other models $(\mathrm{k}=6,37.5 \%)$ as conceptual frameworks.

Intentions were measured in 11 studies. Among them, 8 studies focused on intention to purchase sustainable food in the near future, while the other 3 examined intentions of future consumption of sustainable food.

Two types of behavioral measures were examined: self-reported purchase featured in 6 studies, and observed purchase was examined in 2 studies. Of the latter, both self-reported purchase and observed purchase were investigated in one study (Klöckner \& Ohms 2009), and only self-reported purchase was used in the 
meta-analysis considering that the majority of included studies examined self-reported behavior.

\subsection{Measures}

Because the TPB provides clear definitions and operationalizations of the theoretical constructs, all operational measures that have been used by different researchers were essentially similar. But for some other constructs, such as health concern and ethical concern, scales used for measuring the respective constructs are not always similar. Although narrow and explicitly defined measures could provide conceptual clarity and interpretability of empirical results, any advantage in interpretability of empirical results that narrowly defined measures have over more broadly defined measures is offset by considerations of availability of data and robustness of resulting estimates (Viswesvaran \& Ones, 1995). Also, the usefulness of a construct for making generalizable inferences are likely to increase when the constructs are defined more broadly (Viswesvaran \& Ones, 1995). So we used our set of operational definitions and read the item wordings rather than just relying on authors' labels to guide our coding. The following specific variables were grouped into constructs with somewhat different labels.

Magical Beliefs about Food and Health, which were assessed with the Magical Beliefs about Food and Health Scale (MFH; Lindeman, Keskivaara, \& Roschier, 2000) in one study (Saher et al, 2006), was classified in to the construct of Health Concern, considering that what they measured was the magical thinking or the beliefs about the relationship between food and health and the focus was still health consciousness.

Seven measures were included in the construct of Ethical Concern. Among them, four measures were labeled as Self-identity, which investigated whether consumers considered themselves concerned with environmental issues and whether they considered themselves as environmentally conscious consumers (Michaelidou \& Hassan, 2008; Robinson \& Smith, 2002; Bissonnette \& Contento, 2001; Sparks \& Shepherd, 1992). So they were categorized into the same construct with other measures such as Environmental Attitude, Ecological Motives, and Environmental Protection.

Both Factual Ecological Knowledge and Action-related Ecological Knowledge were measured in one study (Tanner \& Kast, 2003). The term factual knowledge here refers to knowledge about definitions and causes/consequences of environmental problems, whereas action-related knowledge is used to refer to information about possible actions which are related to environmental problems. Since environmental beliefs are directly based on ecological knowledge, it's not easy or necessary to distinguish beliefs from knowledge in the present research. So both of them were included in the construct of Beliefs, and relevant mean correlation coefficients were used.

For the similar reasons mentioned above, after examining the definitions of Awareness of Need (AN: the feeling that action is necessary to prevent a negative outcome for nature) and Awareness of Consequences (AC: awareness that the actor's actions affect nature in a positive or negative way) as well as the examples of survey items in one study (Klöckner \& Ohms, 2009), we categorized the two kinds of awareness into Beliefs, and relevant mean correlation coefficients were used.

Instead of general sustainable food, sustainable dairy products with the hypothetical brand name 'Le Fermier' were under investigation in one study (Vermeir \& Verbeke, 2008). Respondents were asked to indicate their confidence about the true sustainable character of Le Fermier products (e.g., how confident are you that Le Fermier dairy products are effectively ecologically produced / stimulate rural employment, etc.). As we can see, the so called Confidence here is essentially still beliefs about sustainable food, and the beliefs here were just directing to a specific brand name. So it was included into Beliefs in our meta-analysis.

Perceived Responsibility being measured in one study (Bissonnette \& Contento, 2001) refers to how one perceives one's obligation toward a behavior. It was classified into Personal Norm in our meta-analysis because its essence is perceived moral or ethical obligation, which is another expression of personal norm.

The measure of Positive Moral Attitude in one study (Arvola et al., 2008) aims to assess favorable self-evaluations which arise from anticipated compliance with one's own moral principles. Since it's still within the scope of moral obligation, it was also categorized into Personal Norm in our meta-analysis.

Both Perceived Monetary Barriers (Tanner \& Kast, 2003) and Perceived Expensiveness (Thøgersen \& Ölander, 2006) were included into Perceived Behavioral Control in our meta-analysis and the reversed coefficients were used. The measure of Perceived Time Barriers (Tanner \& Kast, 2003) was not used because it focused on respondents' feeling of time shortage for cooking/ preparing meals.

\subsection{Statistical Procedures}

We followed Viswesvaran \& Ones's (1995) 2-step procedure for meta-analytical structural equation modeling. In 
the first stage, psychometric meta-analyses were conduct to estimate the pooled true score correlations between the measures. In the second stage, the estimated pooled correlation matrix was used as input for an SEM path analysis to test the proposed model.

\subsubsection{Meta-analytical Strategy}

Two methods for calculating the pooled correlations in meta-analysis are popular: the Hedges \& Vevea (H-V; 1998) and Hunter \& Schmidt (H-S; 1990) method. One of the main differences between the two methods is that transformed correlation coefficients are used in the $\mathrm{H}-\mathrm{V}$ method while untransformed correlation coefficients are used in the H-S method. Although estimates from both methods were very accurate (Field, 2005), Strube (1988) demonstrated that transformed correlations were less biased than untransformed ones when 3 or fewer studies were included in meta-analysis. 9 constructs were included in the present meta-analysis, which in turn produced 36 off-diagonal cells of pooled effects. Since only 17 of the 36 cells contained more than 3 studies, the H-V method was chosen in the present study, for the purpose of reducing bias through transformed correlations.

To account for measurement error, each original correlation was first adjusted based on the reliability of the two measures (Hunter \& Schmidt, 1990). In cases where reliability statistics were not reported, we used the mean of the reliability reported in other studies included in the meta-analysis within the same construct. The method of adjustment is given in Equation 1, in which $r_{i j}$ is the original correlation coefficient between variable $i$ and variable $\mathrm{j}$, while $\alpha_{\mathrm{i}}$ and $\alpha_{\mathrm{j}}$ are the reliabilities of the two variables

$$
r_{i j_{c}}=\frac{r_{i j}}{\sqrt{\alpha_{i} * \alpha_{j}}}
$$

No attempt was made to correct for range restriction because relevant data (e.g., population means and standard deviations) that would have made this correction possible were unavailable in some studies.

The adjusted correlations were then converted into a standard Normal metric using Fisher's r-to-Z transformation (Fisher, 1921) before calculating a weighted average of these transformed scores. Fisher's (1921) r-to-Z transformation is given in Equation 2 in which $r_{i}$ is the adjusted correlation coefficient from study i:

$$
Z_{r_{i}}=\frac{1}{2} \log _{e}\left(\frac{1+r_{i}}{1-r_{i}}\right)
$$

The transformed effect sizes were then used to calculate an initial average in which each correlation is weighted by the inverse of the within-study variance of the study from which it came (see Equation 3), where $\mathrm{k}$ is the number of studies in the meta-analysis, and $n_{i}$ is the sample size of study $i$ (Hedges \& Olkin, 1985, p. 231):

$$
Z_{c w f}=\frac{\sum_{i=1}^{k} w_{i} Z_{r_{i}}}{\sum_{i=1}^{k} w_{i}}=\frac{\sum_{i=1}^{k}\left(N_{i}-3\right) Z_{r_{i}}}{\sum_{i=1}^{k}\left(N_{i}-3\right)}
$$

After that, the weighted correlation was reconverted back to $r$, see Equation 4:

$$
r_{i}=\frac{e^{\left(2 Z_{i}\right)}-1}{e^{\left(2 Z_{i}\right)}+1}
$$

The unweighted mean effect sizes (see Equation 5) were also calculated and reported considering that they provide complementary information.

$$
r_{u w}=\frac{\sum_{i=1}^{k} N_{i} r_{i}}{\sum_{i=1}^{k} N_{i}}
$$

The statistic Q was used to test the homogeneity of correlations. The statistic Q is given in Equation 6, which has a chi-square distribution with (k-1) degrees of freedom under the null hypothesis of homogenous effect sizes (Hedges \& Olkin, Equation 16, p. 235):

$$
Q=\sum_{i=1}^{k}\left(N_{i}-3\right)\left(Z_{r_{i}}-Z_{c w f}\right)^{2}
$$


The fixed-effects model is appropriate for calculating the pooled correlation matrix when the heterogeneity tests are insignificant, whereas the random-effects model is proper when these tests indicate heterogeneity. The random-effects average correlation is given in Equation 7 (based on Hedges \& Vevea, 1998):

$$
Z_{c w r}=\frac{\sum_{i=1}^{k} W_{i *} Z_{r_{i}}}{\sum_{i=1}^{k} W_{i *}}
$$

Where $\mathrm{W}_{\mathrm{i}^{*}}$ is the weight (calculations see Hedges \& Vevea, 1998), and $Z_{\mathrm{ri}}$ is Fisher's (1921) r-to-Z transformation of the correlation coefficient $r_{i}$ from study $i$.

In cases where the homogeneity assumption does not hold, potential moderators or outliers are typically examined to identify more homogeneous subsets of studies. However, moderator analysis is inappropriate for small numbers of independent studies $(\mathrm{k}<4)$, because it may be difficult to isolate the studies or characteristics responsible for the irregular finding. In such cases, outliers were removed to examine whether heterogeneity could be reduced.

Besides the point estimates, we also reported the 95\%-confidence interval of the correlations calculated under both fixed-effects assumption and random-effects assumption, according to Hedges and Vevea's (1998) recommendation, to estimate variability in the mean effect size.

The upper and lower bounds under fixed-effects assumption are calculated according to Equation 8:

$$
\begin{aligned}
& C I_{\text {upper }-F}=Z_{c w f}+\frac{1.96}{\sqrt{(N-3 k)}} \\
& C I_{\text {lower }-F}=Z_{c w f}-\frac{1.96}{\sqrt{(N-3 k)}}
\end{aligned}
$$

where $\mathrm{Z}_{\mathrm{cwf}}$ is the Fisher's transformed fixed-effects average correlation.

The upper and lower bounds under random-effects assumption are calculated according to Equation 9:

$$
\begin{aligned}
& C I_{\text {upper }-r}=Z_{c w r}+\frac{1.96}{\sqrt{(N-3 k)}} \\
& C I_{\text {lower }-r}=Z_{c w r}-\frac{1.96}{\sqrt{(N-3 k)}}
\end{aligned}
$$

where $Z_{\mathrm{cwr}}$ is the Fisher's transformed random-effects average correlation.

It should be noticed that these values of confidence intervals must be transformed back to the $\mathrm{r}$ metric from Fisher's metric using Equation 4 displayed above.

Since there is a bias in favor of publishing reports of significant results (Hojat et al., 2003), and that empirical studies may be missing and not included in the meta-analysis due to literature search limitations, we reported the 'failsafe N' (Rosenthal, 1979) to address the file drawer problem. Failsafe N estimates the number of unpublished, unretrieved studies with null results that would have to exist in file drawers that would make the significant level of the estimated true effect size down to just significant at the 0.05 level. The larger the failsafe $\mathrm{N}$ the less likely that the result will change due to missing studies. The 'failsafe $\mathrm{N}$ ' is calculated according to Equation 10:

$$
N_{f S(p=0.05)}=\left(\frac{\left(\sum_{i=1}^{k} Z_{i}\right)^{2}}{2.706}\right)-k
$$


Where $Z_{\mathrm{i}}$ is the standard Normal deviate, which can be estimated by $\left(r_{i} \sqrt{N_{i}}\right)$ when the effect size $\mathrm{r}$ is given or can be computed (Rosenthal, 1979).

Rosenthal (1979) also proposed that 'failsafe N' should exceed (5k+10) (the addition of 10 studies would ensure that for very small meta-analytic databases of 1 or 2 studies, the number of unretrieved studies would be 15 or 20 , rather than only 5 or 10). The 'failsafe ratio' is an indicator of the relative sizes of the failsafe number and the Rosenthal standard, and is calculated as Equation 11:

$$
\text { Failsafe Ratio }=\frac{N_{f s(p=0.05)}}{5 k+10}
$$

If the failsafe ratio is less than 1 , then the failsafe $\mathrm{N}$ has not exceeded the $(5 \mathrm{k}+10)$ standard, which indicates that the results are still vulnerable to future null results. If the failsafe ratio exceeds 1 , then the failsafe $\mathrm{N}$ has exceeded the $(5 \mathrm{k}+10)$ standard, which indicates that the results will tolerate future null results.

Considering the potential and inevitable existence of outliers, which contribute to error in the parameter estimates in meta-analysis (Orr et al., 1991), outlier detection was carried out based on Huffcutt and Arthur's (1995) sample-adjusted meta-analytic deviancy statistic or SAMD. The SAMD statistic was noted as a recent methodological advance in meta-analysis (Borman et al., 1997), which takes into account the sample size on which each study is based when determining outlier status.

According to Huffcutt and Arthur (1995), the procedure for computing the variance of the sampling distribution for a particular sample size is shown in Equation 12:

$$
\operatorname{Var}(i)=\frac{\left(1-r_{w / o \text { study }}^{2}\right)^{2}}{N_{i}-1}
$$

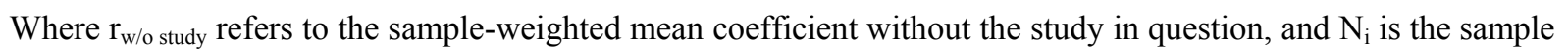
size of that study.

Computing the sampling error variance of a mean coefficient is shown in Equation 13:

$$
\operatorname{Var}(r)=\frac{\left(1-r_{w / o s t u d y}^{2}\right)^{2}}{N-k}
$$

Where $\mathrm{N}$ is the total sample size, and $\mathrm{k}$ is the number of studies used to compute the mean coefficient.

Finally, the SAMD statistic is computed by dividing the raw deviancy for a given study by the sampling standard error of the difference, as shown in Equation 14:

$$
S A M D=\frac{r_{\text {study } i}-r_{w / o \text { study }}}{\sqrt{\operatorname{Var}(i)+\operatorname{Var}(r)}}
$$

According to Huffcutt and Arthur's (1995) recommendation, the SAMD values were calculated for each study in each correlation cell respectively, and then the studies within each correlation cell were rank ordered with respect to the SAMD values. In order to determine which studies constitute outliers, a cutoff SAMD value must be decided. The determination of this value admittedly is somewhat arbitrary, and Beal et al. (2002) examined a variety of cutoff values and determined that SAMD values of \pm 2.0 and \pm 2.25 provided fairly good results. However, considering that only 8 correlational cells contained more than 5 studies in the present meta-analysis, it's impossible to use \pm 2.0 or \pm 2.25 as cutoff SAMD values. Instead, \pm 7.0 was chosen as the cutoff SAMD value, which eliminated approximately $10 \%$ of the studies in those correlation cells that contained more than 3 studies. For those cells containing only 3 studies, the elimination of outliers was quite cautious.

There's another problem that should be considered when identifying outlier studies. In a situation with very discrepant sample sizes (e.g., many studies with sample sizes of 300 or less and 1 study with 3000 subjects), Hunter, Schmidt, and Jackson (1982 p. 41) recommended that meta-analysis be computed twice - once with all studies included in the analysis and once with those studies with outlier sample sizes excluded.

Since both outlier values and outlier sample sizes existed in the present meta-analysis and often appeared as the same study, especially in some correlation cells containing only 3 studies, these two kinds of outlier problems were considered and treated together. According to Hunter, Schmidt, and Jackson's (1982, p. 41) recommendation, meta-analyses were computed twice for each cell - once with all studies included in the analyses and once with the studies without outlier. Results are reported independently. 


\subsubsection{MASEM for Model Testing}

In step 2 of the MASEM, the matrix formed by the true-score population effect sizes of the variable pairs without outliers was subjected to SEM using the LISREL 8.72 (Jöreskog and Sörbom, 2005). Maximum likelihood was chosen as the estimation method in order to assess the correlations as a network of interconnected variables, and we then interpreted and compared goodness-of-fit of the TPB and ETPB models to the data.

Since not all the studies assessed all constructs simultaneously, the pairwise deletion strategy was used to estimate the elements of the pooled correlation. As a result, the sample sizes of each cell were different. Hence, an additional decision must be made as how to equate sample sizes within each cell in the input correlation matrix when these are based on meta-analysis employing different sample sizes. We followed the recommendation of Viswesvaran \& Ones (1995) to use the harmonic mean as the appropriate sample size, because it tends to yield the least biased estimates of standard errors of parameter estimates. The formula for the harmonic mean is displayed in Equation 15:

$$
N_{h m}=\frac{k}{\left(\frac{1}{N_{1}}+\frac{1}{N_{2}}+\cdots+\frac{1}{N_{k}}\right)}
$$

Where $\mathrm{k}$ refers to the number of correlations in the matrix and $\mathrm{N}$ refers to the sample size in each cell. As the formula reveals, the harmonic mean gives less weight to cells with large N's, and therefore is more conservative.

The joint fit index criterion suggested by Hu and Bentler (1999) was used to assess the fit of the two models. This criterion includes the comparative fit index (CFI), root mean square error of approximation (RMSEA), and standardized root mean square residual (SRMR). Specifically, model-data fit was considered acceptable if either of the following fit index combinations were observed: (1) CFI $\geq 0.96$ and $S R M R \leq 0.10$; or (2) SRMR $\leq 0.10$ and $R M S E A \leq 0.06$. Comparison of alternative version of the two models is performed with the Chi-square difference test.

\section{Results}

The results are presented in two parts to address the goals of the present meta-analysis. The first part describes antecedents' effects on intention and behavior of sustainable food consumption, as well as the moderator analyses and outlier analyses that were conducted to identify the potential sources of variation that could affect these relationships. The relationships between all the constructs are also reported in the first part. The second part is the results of meta-analytical structural equation modeling.

\subsection{Traditional Meta-analysis}

As for the traditional meta-analysis of bivariate relationships, the magnitude of antecedents' effects on both intention and behavior of sustainable food consumption was estimated. Cohen's $(1988,1992)$ guidelines were followed to interpret the pooled effects: $r=0.10$ represents a small effect; $r=0.30$ is medium; and $r=0.50$ is large. In cases where heterogeneity tests were significant, we conducted moderator analyses to examine sample and study characteristics that may account for variation across studies. Outlier analyses were also implemented.

\subsubsection{Correlates of Intention}

Table 2 presents results for the meta-analysis of bivariate correlations between antecedents and intention of sustainable food purchase or consumption. Although the correlation between Health Concern and Intention was based on only one study, the original correlation is still reported here for illustrative purposes.

All the other homogeneity tests were rejected except for the correlations between Ethical Concern and Intention. This implies that the random-effects model is appropriate, and moderator analyses should be conducted for those correlations with sufficient number of studies.

As can be seen, all antecedents included in our meta-analysis were significantly related to Intention of sustainable food purchase/consumption. Among them, Personal Norm $\left(\mathrm{r}_{\mathrm{cwr}}=0.63^{* * *}\right)$, Attitude $\left(\mathrm{r}_{\mathrm{cwr}}=0.62^{* * *}\right)$ and Subjective Norm $\left(\mathrm{r}_{\mathrm{cwr}}=0.55^{* * *}\right)$ displayed strongest effects on Intention. The effects of Beliefs $\left(\mathrm{r}_{\mathrm{cwr}}=0.45^{* * *}\right)$, Perceived Behavioral Control $\left(\mathrm{r}_{\mathrm{cwr}}=0.44^{* * *}\right)$ and Ethical Concern $\left(\mathrm{r}_{\mathrm{cwr}}=0.43^{* * *}\right)$ on Intention were also within the scope of medium to large, and in fact were close to large. The correlation between Health Concern and Intention was based on only one study (Michaelidou \& Hassan, 2008), the original correlation $\left(\mathrm{r}=0.25^{* * *}\right.$ ) was also statistically significant.

Moderator analyses were then conducted to examine sample and study characteristics that may account for 
variation across studies. Since moderator analysis requires all studies to provide information on a particular moderator, so only the following four moderators could be coded and examined: sample country (Europe; non-Europe), participants (students or young adults; general), conceptualization of Intention (Intention to purchase; Intention to consume), and theoretical framework (TPB or ETPB; others). We first divided the data into subsets based on the above moderators respectively, and then conducted meta-analyses of each subset, and finally computed a $\mathrm{Z}$ statistic to test whether the characteristic used to divide the data is a moderator (Hunter and Schmidt 1990 p. 438).

However, moderator analyses were impossible for some cells in the correlations matrix, because there was either no variation in the coding of some moderators (e.g., conceptualization of Intention, or theoretical framework), or there was only one study with a different coding. In the latter case, the meta-analytical calculations were conducted again after removing the unique study to examine whether heterogeneity could be reduced. Results of the moderator analyses and the recalculations after removing the unique study are summarized in Table 3 .

As for the Beliefs-Intention relationship, since all the five studies used the TPB or ETPB as theoretical framework, so the moderator analyses or the recalculations were conducted for the other three moderator variables.

The original heterogeneity $\left(\mathrm{Q}=137.25^{* * *}\right)$ could be reduced $\left(\mathrm{Q}=92.60^{* * *}\right)$ by omitting a non-European study, which also had an irregularly low study effect (Robinson \& Smith, 2002; $\mathrm{r}=0.12^{* * *}$ ). Heterogeneity was nearly not reduced by deleting a study choosing young adults as participants (Vermeir \& Verbeke, 2008). The conceptualization of Intention moderated the effect of Beliefs such that the relationship between Beliefs and Intention to purchase $\left(\mathrm{r}_{\mathrm{cwr}}=0.54^{* * *}\right)$ was significantly stronger than that of Intention to consume $\left(\mathrm{r}_{\mathrm{cwr}}=0.32^{* * *}\right)$. And also, heterogeneity test was rejected within the group of Intention to consume, while heterogeneity was still significant within the group of Intention to purchase.

With respect to the Subjective Norm-Intention relationship, the moderator analyses or the recalculations were also conducted for the other three moderator variables except for theoretical framework, because there was no variation in the coding. Results show that Subjective Norm had a significantly larger impact on Intention in European studies $\left(\mathrm{r}_{\mathrm{cwr}}=0.57^{* * *}\right)$ than non- European $\left(\mathrm{r}_{\mathrm{cwr}}=0.48^{* * *}\right)$. Homogeneity was significant within the two non-European samples.

The participants of the samples also affected the magnitude of the SN-Intention relationship. In specific, the general samples $\left(\mathrm{r}_{\mathrm{cwr}}=0.58^{* * * *}\right)$ showed significantly stronger effects than the samples composed of students or young adults $\left(\mathrm{r}_{\mathrm{cwr}}=0.50^{* * *}\right)$.

The original heterogeneity $\left(\mathrm{Q}=93.27^{* * *}\right)$ could be slightly reduced $\left(\mathrm{Q}=73.90^{* * *}\right)$ by omitting a study using Intention to consume as the conceptualization of Intention, which also had the lowest study effect within this cell (Sparks \& Shepherd, 1992; $\mathrm{r}=0.32^{* * *}$ )

As for the Personal Norm-Intention relationship, no moderator analysis could be conducted. Since all the five studies chose TPB or ETPB as framework to investigate the relationships between antecedents and Intention to purchase, the recalculations were implemented based on sample country and participants separately. The original heterogeneity $\left(\mathrm{Q}=32.30^{* * *}\right)$ could be slightly reduced $\left(\mathrm{Q}=22.62^{* * *}\right)$ by omitting a non-European study (Bissonnette \& Contento, 2001), which was also the only study using adolescents as participants in this group of studies.

With respect to the PBC-Intention relationship, the moderator analyses or the recalculations were conducted for the former three moderator variables, because all the nine studies used TPB or ETPB as theoretical framework. The original heterogeneity $\left(\mathrm{Q}=51.50^{* * *}\right)$ was nearly not changed $\left(\mathrm{Q}=48.01^{* * *}\right)$ by omitting a non-European study (Robinson \& Smith, 2002). The general samples $\left(\mathrm{r}_{\mathrm{cwr}}=0.39^{* * *}\right)$ showed significantly lower effects of PBC-Intention relationship than the samples composed of students or young adults $\left(\mathrm{r}_{\mathrm{cwr}}=0.51^{* * *}\right)$. The original heterogeneity $\left(\mathrm{Q}=51.50^{* * *}\right)$ remained nearly the same $\left(\mathrm{Q}=48.68^{* * *}\right)$ after deleting a study investigating Intention to consume (Sparks \& Shepherd, 1992)

All the four sets of the moderator analyses were conducted for the Attitude-Intention relationship. The results show that European samples $\left(\mathrm{r}_{\mathrm{cwr}}=0.63^{* * *}\right)$ yielded slightly but significantly stronger Attitude-Intention relationship than non-European samples $\left(\mathrm{r}_{\mathrm{cwr}}=0.58^{* * *}\right)$. Homogeneity was significant within the two non-European samples. Students or young adults samples $\left(\mathrm{r}_{\mathrm{cwr}}=0.67^{* * *}\right)$ showed significantly larger effect size of Attitude-Intention relationship than the general samples $\left(\mathrm{r}_{\mathrm{cwr}}=0.60^{* * *}\right)$. The results further showed that the Attitude-Intention relationship was significantly stronger when Intention to purchase $\left(\mathrm{r}_{\mathrm{cwr}}=0.67^{* * *}\right)$ was measured, compared to Intention to consume $\left(\mathrm{r}_{\mathrm{cwr}}=0.41^{* * *}\right)$. The Attitude-Intention relationship was significantly 
stronger when TPB or ETPB was used as theoretical framework $\left(\mathrm{r}_{\mathrm{cwr}}=0.63^{* * *}\right)$, compared to others ( $\mathrm{r}_{\mathrm{cwr}}$ $=0.56^{* * *}$ ).

It could be summarized based on the present moderator analyses that, European samples had significantly stronger relationships for sustainable food purchasing/consumption intention with Subjective Norm and Attitude. The general samples showed significantly stronger relationship for Intention with Subjective Norm, but weaker relationships with PBC and Attitude. The relationships for Beliefs and Attitude with Intention were significantly stronger when Intention to purchase was measured, compared to Intention to consume. Using TPB or ETPB as theoretical framework yielded significantly stronger Attitude-Intention relationship.

Robinson and Smith's study $\left(\mathrm{r}_{\mathrm{c}}=0.12, \mathrm{~N}=547\right.$; 2002) within the correlation cell of Beliefs-Intention and Honkanen et al.'s study $\left(r_{c}=0.40, N=1283 ; 2006\right)$ within the correlation cell of Attitude-Intention were detected as outliers based on the criteria mentioned above. Computations were implemented again after elimination, and results are shown in Table 4.

As can be seen, the homogeneity tests were still rejected although the Q statistics were reduced after the elimination of the outliers.

\subsubsection{Correlates of Behavior}

Table 5 presents results for the meta-analysis of bivariate correlations between antecedents and behavior of sustainable food purchase or consumption. Although the correlations between Health Concern and Ethical Concern with Intention were based on one same study, the original correlations are still reported here for illustrative purposes.

The homogeneity test for the Beliefs-Behavior relationship could not be rejected, whereas the other homogeneity tests were all rejected. This implies that the random-effects model is appropriate, and moderator analyses should be conducted. Unfortunately, only the correlations between PBC and Behavior contained 4 independent studies, which is the threshold number for moderator analysis.

All antecedents included in our meta-analysis were significantly related to Behavior of sustainable food purchase/consumption. Among them, Personal Norm $\left(\mathrm{r}_{\mathrm{cwr}}=0.70^{* * *}\right)$, Attitude $\left(\mathrm{r}_{\mathrm{cwr}}=0.58^{* * *}\right)$ and Subjective Norm $\left(\mathrm{r}_{\mathrm{cwr}}=0.53^{* * *}\right)$ showed the strongest effects on Behavior. The effects of Intention $\left(\mathrm{r}_{\mathrm{cwr}}=0.46^{* * *}\right)$, Beliefs $\left(\mathrm{r}_{\mathrm{cwr}}\right.$ $\left.=0.38^{* * *}\right)$ and Perceived Behavioral Control $\left(\mathrm{r}_{\mathrm{cwr}}=0.38^{* * *}\right)$ were also within the scope of medium to large. The correlations between Health Concern, Ethical Concern and Behavior were based on the same study (Tanner \& Kast, 2003), and the original correlations were significant at 0.001 level.

The following four moderators could be coded and examined: sample country (Europe; non-Europe), participants (students or young adults; general), conceptualization of Behavior (self-reported purchase; observed purchase), and theoretical framework (TPB or ETPB; others). As mentioned above, moderator analysis was only possible for the PBC-Behavior relashionship. For other relationships, recalculations were conducted after removing one unique study to examine whether heterogeneity could be reduced. Results of the moderator analysis and the recalculations after removing the unique study are summarized in Table 6.

As for the Subjective Norm-Behavior relationship, the original heterogeneity $\left(\mathrm{Q}=263.66^{* * *}\right)$ could be reduced largely $\left(\mathrm{Q}=35.38^{* * *}\right)$, but remained significant by omitting a study recruiting university students as participants (Bamberg, 2002), which also differed from the other two studies since it measured observed purchase. Heterogeneity was nearly not reduced by deleting a study that had chosen another theoretical framework than the TPB or ETPB (Klöckner \& Ohms, 2009). It should be noticed that there was an irregularly strong study effect (r $=0.82^{* * *}$; Thøgersen and Ölander, 2006), and the heterogeneity test could be rejected $\left(\mathrm{Q}=1.58 ; \mathrm{r}_{\mathrm{cwf}}=0.23^{* * *} ; \mathrm{r}_{\mathrm{cwr}}\right.$ $=0.25^{* * *}$ ) when it was omitted.

With respect to the Personal Norm-Behavior relationship, the heterogeneity test could be rejected $(\mathrm{Q}=1.2 .43$; $\mathrm{r}_{\mathrm{cwf}}=0.46^{* * *} ; \mathrm{r}_{\mathrm{cwr}}=0.50^{* * *}$ ) by omitting the only one study using ETPB as the theoretical framework (Thøgersen and Ölander, 2006), which also showed an irregularly strong study effect $\left(\mathrm{r}=0.89^{* * *}\right)$.

As for the PBC-Behavior relationship, the original heterogeneity $\left(\mathrm{Q}=31.88^{* * *}\right)$ almost remained the same $(\mathrm{Q}$ $=30.18^{* * *}$ ) by omitting a study recruiting university students as participants (Bamberg, 2002), which also differed from the other two studies since it measured observed purchase. The theoretical framework moderated the effect of PBC such that the PBC-Behavior relationship under the TPB or ETPB framework $\left(\mathrm{r}_{\mathrm{cwr}}=0.31^{* * *}\right)$ was significantly weaker than that under other frameworks $\left(\mathrm{r}_{\mathrm{cwr}}=0.47^{* * *}\right)$.

With respect to the Attitude-Behavior relationship, the original heterogeneity $\left(\mathrm{Q}=459.75^{* * *}\right)$ remained significant $\left(Q=352.79^{* * *}\right)$ by omitting a study with university students as participants (Bamberg, 2002), which 
also differed from the other two studies since it measured observed purchase. But heterogeneity could be reduced largely $\left(\mathrm{Q}=4.46^{*}\right)$ if one study with an irregularly strong study effect $\left(\mathrm{r}=0.84^{* * *}\right.$; Thøgersen and Ölander, 2006) was omitted.

As for the Intention-Behavior relationship, the original heterogeneity test $\left(\mathrm{Q}=7.88^{*}\right)$ could be rejected $(\mathrm{Q}=0.85)$ within the two studies selecting adolescents or university students as participants (Bissonnette \& Contento, 2001; Bamberg, 2002). While after deleting one study in which observed purchase was measured (Bamberg, 2002), heterogeneity was reduced to just above the crucial value to be significant at 0.05 level $\left(\mathrm{Q}=3.88^{*}\right)$.

Thøgersen and Ölander's study (2006) was eliminated from 4 correlational cells (SN-Behavior, PN-Behavior, PBC-Behavior, Attitude-Behavior, respectively), because it was detected as having an outlier sample size $(\mathrm{N}=1520)$ as well as extremely high effect size in three cells and extremely low effect size in the final cell. Computations were implemented again after elimination, and results are shown in Table 7.

After the elimination of outliers, the former three homogeneity tests were accepted while the heterogeneity in the last dimension was largely reduced to being significant at 0.05 level. However, the failsafe ratio of the SN-Behavior relationship didn't exceed the $(5 \mathrm{k}+10)$ standard, which indicates that the result was still vulnerable to future null results.

\subsubsection{Correlates of Constructs}

Table 8 presents total sample size and number of independent correlation matrices included in each construct pair after the outliers were eliminated. As can be seen, the correlation coefficient between Health Concern and Subjective Norm was vacant. And also, the correlation between Health Concern and the other five constructs (Beliefs, Personal Norm, Perceived Behavioral Control, Intention and Behavior) were based on one single study respectively. Ethical Concern was another construct which hadn't been paid enough attention to. Although the antecedents of Intention in the sustainable food domain are largely similar to those in the general pro-environmental behavior literature, however, Health Concern and Ethical Concern are still important antecedents which could provide unique explanation for the purchase and consumption of sustainable food. This underlines that future research should include characteristic antecedents for a better understanding of sustainable food purchase and consumption.

Correlations of Ethical Concern-PN as well as Ethical Concern-Behavior were also based on one study. Within the ETPB constructs, correlations of 3 pairs (SN-Behavior; PN-Behavior; Attitude-Behavior) were derived from two studies. Although meta-analysis is not suitable for summarizing data from only two studies, such results were still input into MASEM analysis for illustrative purposes.

The meta-analyzed correlation matrix under both fixed-effects and random-effects assumption without outliers is shown in Table 9. Table 10 reports the $95 \%$ confidence intervals of these estimates.

\subsection{Meta-Analytic Structural Equation Modeling}

In addition to meta-analysis of bivariate relationships of antecedents with Intention and Behavior, the random-effects correlation matrix (lower triangular matrix) in Table 9 was used as input for the MASEM test of the structural relations of the TPB and ETPB models. Since the sample sizes of each cell were different, the harmonic means of sample size $(\mathrm{N}=1399$ for TPB; $\mathrm{N}=1210$ for ETPB) were used in the MASEM analysis. As mentioned before, use of the harmonic mean results in more conservative estimates, as less weight is given to large samples.

Table 11 presents the fit indices of the TPB and ETPB models, each of which produced statistically acceptable fit indices, according to the joint fit index criterion suggested by $\mathrm{Hu}$ and Bentler (1999) (CFI $\geq 0.96$ and SRMR $\leq 0.10$; or $S R M R \leq 0.10$ and RMSEA $\leq 0.06$ ). The TPB Model produced similar and slightly better CFI, SRMR, and RMSEA values as well as lower chi-square values than did the ETPB model.

Results of parameter estimates (standardized path coefficients and explained variances) are presented in Figure 2 and Figure 3 for the TPB and ETPB models respectively. All the paths were statistically significant at 0.05 level.

Both the TPB and the ETPB models indicated that Intention mediated the association of other psycho-social variables with Behavior of sustainable food purchase/consumption. Based on the TPB model, PBC, Attitude, and Subjective Norm explained on average $48 \%$ of variance of Intention to purchase/consume sustainable food, while Intention in turn explained on average $28 \%$ of variance of the Behavior. A slight increase (3\%) was made to the amount of explained variance of Intention by adding Personal Norm to the TPB, while the amount of explained variance of Behavior was almost the same.

The main differences between the two models lie in the relationships between Intention and the other three 
antecedents: Personal Norm, Subjective Norm and Attitude. After adding Personal Norm in TPB, the standardized path coefficients of Attitude-Intention and SN-Intention were reduced from 0.42 to 0.25 and from 0.22 to 0.14 respectively, and Personal Norm became the most important predictor of Intention (0.30). The role of Subjective Norm in predicting Intention became twofold: direct influence and indirect influence through Personal Norm. However, the PBC-Intention relationship remained almost the same, regardless PN was added or not. Results of MASEM for ETPB model indicated that Personal Norm significantly and independently accounted for variations of Intention over the other antecedents of the TPB model.

It is interesting that the most important predictor of Intention was Personal Norm, i.e., individuals' convictions that purchasing/consuming sustainable food is right or wrong. Those consumers who intend to purchase/consume sustainable food in the future tend to perceive their behavior as morally right or correct. Subjective Norm still succeeded to remain in the model after Personal Norm was added, but its weight was much lower than the other three antecedents of Intention. It must be noted that Ajzen (1991) argued that the weight of the predictors of TPB might be varying with the behavior under study. Since the purchase and consumption of sustainable food are relatively private, it could be argued that Subjective Norm is not of primary concern to consumers. Instead, consumers rely more on Personal Norms, which are influenced by Subjective Norm.

Because the models allow relationships to be mediated by other variables, the standardized total effects rather than direct effects was considered and are shown in Table 12 for the TPB and ETPB, respectively. The total effects represent the sum of both direct and mediated indirect effects through which a predictor influences a dependant variable. As can be seen, the total effect of PBC on Behavior in both TPB (0.36) and ETPB (0.36) models was slightly higher than that of Intention ( 0.34 and 0.33 for TPB and ETPB respectively). As for the total effects of antecedents on Intention, Attitude (0.42) showed highest total effects in the TPB model, while Subjective Norm (0.32) showed biggest total effects followed by Personal Norm $(0.30)$ in the ETPB model. It deserves attention that total effects depend on the validity of the present model and they should be viewed as correlations instead of causal relationships.

\section{Conclusion and Discussion}

This MASEM study aims to provide an overview of existing antecedents of sustainable food consumption within an integrative framework based on the TPB. As expected, all antecedents included in our meta-analysis were significantly related to Intention of sustainable food purchase/consumption. Among them, Personal Norm $\left(\mathrm{r}_{\mathrm{cwr}}\right.$ $\left.=0.63^{* * *}\right)$, Attitude $\left(\mathrm{r}_{\mathrm{cwr}}=0.62^{* * *}\right)$ and Subjective Norm $\left(\mathrm{r}_{\mathrm{cwr}}=0.55^{* * *}\right)$ displayed strongest effects on Intention. The effects of Beliefs $\left(\mathrm{r}_{\mathrm{cwr}}=0.45^{* * *}\right)$, Perceived Behavioral Control $\left(\mathrm{r}_{\mathrm{cwr}}=0.44^{* * *}\right)$ and Ethical Concern $\left(\mathrm{r}_{\mathrm{cwr}}\right.$ $\left.=0.43^{* * *}\right)$ on Intention were also within the scope of medium to large, and in fact were close to large. The correlation between Health Concern and Intention was based on only one study (Michaelidou \& Hassan, 2008), the original correlation $\left(\mathrm{r}=0.25^{* * *}\right)$ was also statistically significant. All antecedents included in our meta-analysis were also significantly related to Behavior of sustainable food purchase/consumption. Among them, Personal Norm $\left(\mathrm{r}_{\mathrm{cwr}}=0.70^{* * *}\right)$, Attitude $\left(\mathrm{r}_{\mathrm{cwr}}=0.58^{* * *}\right)$ and Subjective Norm $\left(\mathrm{r}_{\mathrm{cwr}}=0.53^{* * *}\right)$ showed strongest effects on Behavior. The effects of Intention $\left(\mathrm{r}_{\mathrm{cwr}}=0.46^{* * *}\right)$, Beliefs $\left(\mathrm{r}_{\mathrm{cwr}}=0.38^{* * * *}\right)$ and Perceived Behavioral Control $\left(\mathrm{r}_{\mathrm{cwr}}\right.$ $=0.38^{* * *}$ ) were also within the scope of medium to large. The correlations between Health Concern, Ethical Concern and Behavior were based the same one study (Tanner \& Kast, 2003), the original correlation were also significant at 0.001 level.

As for the moderator analyses, European samples had significantly stronger relationships for sustainable food purchasing/consumption intention with Subjective Norm and Attitude. The general samples showed significantly stronger relationship for Intention with Subjective Norm, but weaker relationships with PBC and Attitude. The relationships for Beliefs and Attitude with Intention were significantly stronger when Intention to purchase was measured, compared to Intention to consume. Using TPB or ETPB as theoretical framework yielded significantly stronger relationships for Attitude with Intention to purchase/consume sustainable food.

The present study also tries to compare TPB with the extended version of TPB, which adds Personal Norm as independent antecedent of intention, in their powers of explaining the intention and behaviors in the sustainable food domain. As we hypothesized, the results of this MASEM study suggest that both TPB and ETPB models have statistically acceptable power in explaining the intention and behavior of sustainable food consumption. The results also support the hypothesis that ETPB is superior to TPB in doing that, even only a slight increase (3\%) was made to the amount of explained variance of Intention by adding Personal Norm to TPB, while the amount of explained variance of Behavior remained almost unchanged.

The results of our meta-analyses give readers an understanding of the magnitude and significance of relationships between antecedents and intention in the sustainable food consumption domain. The results of 
moderator analyses, even not sufficient enough due to the relatively small amount of studies, also shed some light on sources of inconsistencies or divergence of different research results. These MASEM findings provide a valuable complement to the findings of individual primary studies because the two-step MASEM procedure allowed us to test all the relations specified in the models simultaneously.

The results of this meta-analysis should be interpreted in the context of its limitations. First, the correlations related to Behavior were derived from only 2 or 3 individual samples excluding 1 outlier for each of the variables SN, PN, Attitude, and PBC. Such relatively small samples may be insufficient to detect the impact of antecedents on the correlations regarding sustainable food purchase/consumption behavior. This could be the reason that the explained variance of Behavior was not increased after PN had been added into the TPB model. However, this limitation should not excessively influence our results since the MASEM approach is more dependent on sample sizes rather than number of studies (Viswesvaran \& Ones, 1995). And also, meta-analytic findings may be expected to provide more robust findings than those of individual primary studies. Second, in cases that the reliability alphas were relatively low (e.g., Tanner \& Kast, 2003), the corrected correlations could be overestimated. The availability of more primary studies would cancel out large attenuation-effects. Finally, the statistical theories of meta-analysis and structural equation modeling are based on the distributions of correlations and covariance matrices respectively. In the present MASEM, the correlation matrix rather than the covariance matrix was put into LISREL 8.72 (Jöreskog and Sörbom, 2005) to estimate the path coefficients in the structural model. Replacing covariance matrix by correlation matrix in SEM may produce incorrect chi-square statistics and incorrect standard errors of parameter estimates (Cudeck, 1989; Jöreskog \& Sörbom, 2005). However, since these standard errors are often overestimated by doing so (Cudeck, 1989), the significance tests of individual parameters should be more conservative.

Despite of these methodological constraints, the present study contributes to the application and modification of the TPB as well as the sustainable food consumption domain by performing the first MASEM test of models of TPB and ETPB within the field of sustainable food consumption. Our study also indicates some directions of future research. First, future research should include characteristic antecedents beside the determinants of general pro-environmental behavior for a better understanding of sustainable food purchase and consumption. Second, future research may pay more attention to the actual behaviors of sustainable food consumption instead of focusing narrowly on intention.

\section{References}

Aertsens, J., Verbeke, W., Mondelaers, K., \& Huylenbroeck, G. V. (2009). Personal determinants of organic food consumption: a review. British Food Journal, 111, 1140-1167. http://dx.doi.org/10.1108/00070700910992961

Ajzen, I. (1985). From intention to actions: A theory of planned behavior. In J. Kuhl \& J. Beckman (Eds.), Actions-control: From cognition to behavior. Heidelberg: Springer.

Ajzen, I. (1988). Attitudes, personality and behavior. Chicago: Dorsey Press.

Ajzen, I. (1991). The theory of planned behavior. Organizational Behavior and Human Decision Processes, 50, 179-211. http://dx.doi.org/10.1016/0749-5978(91)90020-T

Ajzen, I., \& Fishbein, M. (1980). Understanding attitudes and predicting social behavior. Englewood Cliffs, NJ: Prentice-Hall.

Armitage, C. J., \& Conner, M. (2001). Efficacy of the theory of planned behaviour: A meta-analytic review. British Journal of Social Psychology, 40, 471-499. http://dx.doi.org/10.1348/014466601164939

Arvola, A., Vassallo, M., Dean, M., Lampila, P., Saba, A., Lähteenmäki, L., \& Shepherd, R. (2008). Predicting intention to purchase organic food: The role of affective and moral attitudes in the Theory of Planned Behavior. Appetite, 50, 443-454. http://dx.doi.org/10.1016/j.appet.2007.09.010

Bamberg, S., \& Moser, G. (2007). Twenty years after Hines, Hungerford, and Tomera: a new meta-analysis of psycho-social determinants of pro-environmental behavior. Journal of Environmental Psychology, 27, 14-25. http://dx.doi.org/10.1016/j.jenvp.2006.12.002

Bamberg, S. (2002). Implementation intention versus monetary incentive comparing the effects of interventions to promote the purchase of organically produced food. Journal of Economic Psychology, 23, 573-587. http://dx.doi.org/10.1016/S0167-4870(02)00118-6

Beal, Daniel. J., Corey, D. M., \& Dunlap, W. P. (2002). On the Bias of Huffcutt and Arthur's (1995) Procedure for Identifying Outliers in the Meta-Analysis of Correlations. Journal of Applied Psychology, 87, 583-589.

Bissonnette, M. M., \& Contento, I. R. (2001). Adolescents' Perspectives and Food Choice Behaviors in Terms of 
the Environmental Impacts of Food Production Practices: Application of a Psychosocial Model. Journal of Nutrition Education, 33, 72-82. http://dx.doi.org/10.1016/S1499-4046(06)60170-X

Borman, W. C., Hanson, M. A., \& Hedge, J. W. (1997). Personnel selection. Annual Review of Psychology, 48, 299-337. http://dx.doi.org/10.1146/annurev.psych.48.1.299

Caplan, P., Keane, A., Willetts, A., \& Williams, J. (1998). Studying food choice in its social and cultural contexts: Approaches from a social anthropological perspective. In A. Murcott (Ed.), The Nation's diet: The social science of food choice (pp. 168-182). London/New York: Longman.

Chen, M. F. (2007). Consumer attitudes and purchase intention in relation to organic foods in Taiwan: moderating effects of food-related personality traits. Food Quality and Preference, 18, 1008-21. http://dx.doi.org/10.1016/j.foodqual.2007.04.004

Cohen, J. (1988). Statistical power analysis for the behavioral sciences (2nd Ed.). Hillsdale: Erlsbaum.

Cohen, J. (1992). A power primer. Psychological Bulletin, 112, 155-159. http://dx.doi.org/10.1037/0033-2909.112.1.155

Conner, M. T. (1993). Individualized measurement of attitudes towards foods. Appetite, 20, 235-238. http://dx.doi.org/10.1006/appe.1993.1026

Conner, M., \& Armitage, C. (1998). Extending the theory of planned behavior: A review and avenues for future

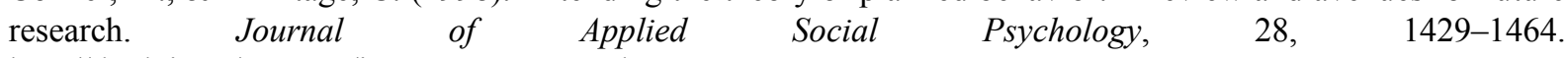
http://dx.doi.org/10.1111/j.1559-1816.1998.tb01685.x

Cooke, R., \& French, D. P. (2008). How well do the theory of reasoned action and theory of planned behavior predict intention and attendance at screening programmes? A meta-analysis. Psychology and Health, 23, 745-765. http://dx.doi.org/10.1080/08870440701544437

Cudeck, R. (1989). Analysis of Correlation Matrices Using Covariance Structure Model. Psychological Bulletin, 705, 317-327. http://dx.doi.org/10.1037/0033-2909.105.2.317

Dean, M., Raats, M. M., \& Shepherd, R. (2008). Moral concerns and consumer choice of fresh and processed

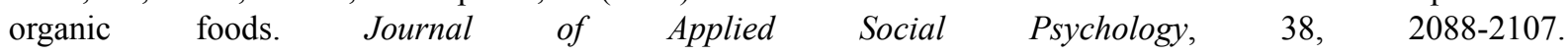
http://dx.doi.org/10.1111/j.1559-1816.2008.00382.x

Field, A. P. (2005). Is the Meta-Analysis of Correlation Coefficients Accurate When Population Correlations Vary? Psychological Methods, 10, 444-467. http://dx.doi.org/10.1037/1082-989X.10.4.444

Fisher, R. A. (1921). On the probable error of a coefficient of correlation deduced from a small sample. Metron, $1,3-32$.

Furst, T., Connors, M., Bisogni, C.A., Sobal, J., \& Falk, L.W. (1996). Food choice: a conceptual model of the process. Appetite, 26, 247-66. http://dx.doi.org/10.1006/appe.1996.0019

Gardner, B., \& Abraham, C. (2008). Psychological correlates of car use: A meta-analysis. Transportation Research, Part F 11, 300-311. http://dx.doi.org/10.1016/j.trf.2008.01.004

Godin, G., \& Kok, G. (1996). The theory of planned behavior: A review of its applications to health-related behaviors. American Journal of Health Promotion, 11, 87-98. http://dx.doi.org/10.4278/0890-1171-11.2.87

Guido, G., Prete, M. I., Peluso, A. M., Maloumby-Baka, R. C., \& Buffa, C. (2010). The role of ethics and product personality in the intention to purchase organic food products: a structural equation modeling approach. International Review of Economics, 57, 79-102. http://dx.doi.org/10.1007/s12232-009-0086-5

Harland, P., Staats, H., \& Wilke, H. A. M. (1999). Explaining pro-environmental intention and behavior by personal norms and the theory of planned behavior. Journal of Applied Social Psychology, 29, 2505-2528. http://dx.doi.org/10.1111/j.1559-1816.1999.tb00123.x

Hedges, L. V., \& Olkin, I. (1985). Statistical methods for meta-analysis. Orlando, FL: Academic Press.

Hedges, L. V., \& Vevea, J. L. (1998). Fixed- and random-effects models in meta-analysis. Psychological Methods, 3, 486-504. http://dx.doi.org/10.1037/1082-989X.3.4.486

Heneman, R. L. (1986). The Relationship between Supervisory Ratings and Results-Oriented Measures of Performance: A Meta-Analysis. Personal Psychology, 39, 811-826.

Hojat M., Gonnella J. S., \& Caelleigh A. S. (2003). Impartial judgment by the "gatekeepers" of science: fallibility and accountability in the peer review process. Advances In Health Sciences Education: Theory And 
Practice, 8, 75-96. http://dx.doi.org/10.1023/A:1022670432373

Honkanen, P., Verplanken, B., \& Olsen, S. O. (2006). Ethical values and motives driving organic food choice. Journal of Consumer Behaviour, 5, 420-430. http://dx.doi.org/10.1002/cb.190

Hu, L., \& Bentler, P. M. (1999). Cutoff criteria for fit indexes in covariance structure analysis: Conventional criteria versus new alternatives. Structural Equation Modeling, 6, 1-55. http://dx.doi.org/10.1080/10705519909540118

Huffcutt, A. I., \& Arthur, W. A. (1995). Development of a new outlier statistic for meta-analytic data. Journal of Applied Psychology, 80, 327-334. http://dx.doi.org/10.1037/0021-9010.80.2.327

Hughner, R. S., McDonagh, P., Prothero, A., Shultz II, C. J., \& Stanton, J. (2007). Who are organic food consumers? A compilation and review of why people purchase organic food. Journal of Consumer Behavior, 6 , 94-110. http://dx.doi.org/10.1002/cb.210

Hunter, J. E., \& Schmidt, F. L. (1990). Methods of meta-analysis: Correcting error and bias in research findings. Newbury Park, CA: Sage.

Jöreskog, K., \& Sörbom, D. (2005). LISREL 8.72. Scientific Software International, Lincolnwood, IL.

Klöckner, C. A., \& Ohms, S. (2009). The importance of personal norms for purchasing organic milk. British Food Journal, 111, 1173-1187. http://dx.doi.org/10.1108/00070700911001013

Köster, E. P. (2009). Diversity in the determinants of food choice: A psychological perspective. Food Quality and Preference, 20, 70-82. http://dx.doi.org/10.1016/j.foodqual.2007.11.002

Lindeman, M., Keskivaara, P., \& Roschier, M. (2000). Assessment of magical beliefs about food and health. Journal of Health Psychology, 5, 195-209. http://dx.doi.org/10.1177/135910530000500210

Lodorfos, G. N., \& Dennis, J. (2008). Consumers' Intent: In the Organic Food Market. Journal of Food Products Marketing, 14, 17-38. http://dx.doi.org/10.1080/10454440801918218

Lusk, J. L., \& Briggeman, B. C. (2009). Food values. American Journal of Agricultural Economics, 91, 184-196. http://dx.doi.org/10.1111/j.1467-8276.2008.01175.x

McDonald, S., Oates, C., Thyne, M., Alevizou, P., \& McMorland, L. (2009). Comparing sustainable consumption patterns across product sectors. International Journal of Consumer Studies, 33, 137-145. http://dx.doi.org/10.1111/j.1470-6431.2009.00755.x

Michaelidou, N., \& Hassan, L. M. (2008). The role of health consciousness, food safety concern and ethical identity on attitudes and intention towards organic food. International Journal of Consumer Studies, 32, 163-170. http://dx.doi.org/10.1111/j.1470-6431.2007.00619.x

Mondelaers K., Aertsens J., \& Huylenbroeck G. V. (2009). A meta-analysis of the differences in environmental impacts between organic and conventional farming. British Food Journal, 111, 1098-1119. http://dx.doi.org/10.1108/00070700910992925

Orr, J. M., Sackett, P. R., \& DuBois, C. Z. (1991). Outlier detection and treatment in I/O psychology: A survey of researcher beliefs and an empirical illustration. Personnel Psychology, 44, 473-486. http://dx.doi.org/10.1111/j.1744-6570.1991.tb02401.x

Pettinger, C., Holdsworth, M., \& Gerber, M. (2004). Psycho-social influences on food choice in Southern France and Central England. Appetite, 42, 307-316. http://dx.doi.org/10.1016/j.appet.2004.01.004

Prescott, J., Young, O., O’Neill, L., Yau, N. J. N., \& Stevens. R. (2002). Motives for food choice: a comparison of consumers from Japan, Taiwan, Malaysia and New Zealand. Food Quality and Preference, 13, 489-495. http://dx.doi.org/10.1016/S0950-3293(02)00010-1

Robinson, R., \& Smith, C. (2002). Psychosocial and Demographic Variables Associated with Consumer Intention to Purchase Sustainably Produced Foods as Defined by the Midwest Food Alliance. Journal of Nutrition Education \& Behavior, 34, 316-325. http://dx.doi.org/10.1016/S1499-4046(06)60114-0

Rokeach, M. J. (1973). The Nature of Human Values. The Free Press, New York, NY.

Rosenthal, R. (1979). The "file drawer problem" and tolerance for null results. Psychological Bulletin, 86, 638-641. http://dx.doi.org/10.1037/0033-2909.86.3.638

Saba, A., \& Messina, F. (2003). Attitudes towards organic foods and risk/benefit perception associated with pesticides. Food Quality and Preference, 14, 637-645. http://dx.doi.org/10.1016/S0950-3293(02)00188-X 
Saher, M., Lindeman, M., \& Hursti, U. K. (2006). Attitudes towards genetically modified and organic foods. Appetite, 46, 324-331. http://dx.doi.org/10.1016/j.appet.2006.01.015

Schwartz, S. H. (1992). Universals in the content and structure of values: theoretical advances and empirical tests in 20 countries. Advances in Experimental Social Psychology, 25, 65. http://dx.doi.org/10.1016/S0065-2601(08)60281-6

Shadish W. R. (1996). Meta-analysis and the exploration of causal mediating process: A primer of examples, methods, and issues. Psychological Methods, 1, 47-65. http://dx.doi.org/10.1037/1082-989X.1.1.47

Sheeran, P., \& Taylor, S. (1999). Predicting intention to use condoms: Meta-analysis and comparison of the theories of reasoned action and planned behavior. Journal of Applied Social Psychology, 29, 1624-1675. http://dx.doi.org/10.1111/j.1559-1816.1999.tb02045.x

Shepherd, R., \& Raats, M. (1996). Attitudes and beliefs in food habits. In H. L. Meiselman, \& H. J. H. MacFie (Eds.), Food choice, acceptance and consumption (pp. 346-364). London: Blackie. http://dx.doi.org/10.1007/978-1-4613-1221-5_10

Sparks, P., \& Shepherd, R. (1992). Self-Identity and the Theory of Planned Behavior: Assessing the Role of Identification with "Green Consumerism". Social Psychology Quarterly, 55, 388-399. http://dx.doi.org/10.2307/2786955

Steptoe, A., Pollard, T. M., \& Wardle, J. (1995). Development of a measure of the motives underlyingthe selection of food: the Food Choice Questionnaire. Appetite, 25, 267-284. http://dx.doi.org/10.1006/appe.1995.0061

Strube, M. J. (1988). Averaging correlation coefficients: Influence of heterogeneity and set size. Journal of Applied Psychology, 73, 559-568. http://dx.doi.org/10.1037/0021-9010.73.3.559

Tanner, C., \& Kast, S. W. (2003). Promoting Sustainable Consumption: Determinants of Green Purchases by Swiss Consumers. Psychology \& Marketing, 20, 883-902. http://dx.doi.org/10.1002/mar.10101

Thøgersen, J., \& Ölander, F. (2006). The Dynamic Interaction of Personal Norms and Environment-Friendly Buying Behavior: A Panel Study. Journal of Applied Social Psychology, 36, 1758-1780. http://dx.doi.org/10.1111/j.0021-9029.2006.00080.x

UNCED. (1992). Agenda 21 and the UNCED Proceedings. Oceana Pblicationa, New York.

Vermeir, I., \& Verbeke, W. (2008). Sustainable food consumption among young adults in Belgium: Theory of planned behaviour and the role of confidence and values. Ecological Economic, 64, 542-553. http://dx.doi.org/10.1016/j.ecolecon.2007.03.007

Viswesvaran, C., \& Ones, D. S. (1995). Theory testing: Combining psychometric meta-analysis and structural equation modeling. Personnel Psychology, 48, 865-885. http://dx.doi.org/10.1111/j.1744-6570.1995.tb01784.x 
Table 1. Features of studies included in the meta-analysis

\begin{tabular}{|l|l|l|l|l|l|l|}
\hline Reference & $\begin{array}{l}\text { Sample } \\
\text { Country }\end{array}$ & $\mathrm{N}$ & Participants & $\begin{array}{l}\text { Age range } \\
\text { (Mean) }\end{array}$ & $\begin{array}{l}\text { Gender } \\
\text { (Female \%) }\end{array}$ & $\begin{array}{l}\text { Theoretical } \\
\text { Framework }\end{array}$ \\
\hline $\begin{array}{l}\text { Guido et al. } \\
(2010)\end{array}$ & France, Italy & 207 & General & $15 \sim 66+$ & - & $\begin{array}{l}\text { FFM \& } \\
\text { ETPB }\end{array}$ \\
\hline Chen (2009) & Taiwan & 470 & General & $20+$ & - & Other \\
\hline $\begin{array}{l}\text { Klöckner \& } \\
\text { Ohms (2009) }\end{array}$ & Germany & 63 & General & $21 \sim 87(41)$ & $68 \%$ & Other \\
\hline $\begin{array}{l}\text { Arvola et al. } \\
\text { (2008) }\end{array}$ & $\begin{array}{l}\text { Italy, } \\
\text { Finland, UK }\end{array}$ & 672 & General & $18 \sim 65$ & $\begin{array}{l}\text { Finland } \\
\text { co\%); other } \\
\text { countries } \\
(70-72 \%)\end{array}$ & TPB \\
\hline $\begin{array}{l}\text { Lodorfos \& } \\
\text { Dennis (2008) }\end{array}$ & UK & 144 & General & $<18 \sim 45+$ & - & TPB \\
\hline $\begin{array}{l}\text { Michaelidou \& } \\
\text { Hassan (2008) }\end{array}$ & UK & 222 & General & $15 \sim 65$ & $72 \%$ & Other \\
\hline $\begin{array}{l}\text { Vermeir \& } \\
\text { Verbeke(2008) }\end{array}$ & Belgium & 456 & Young adults & $19 \sim 22$ & - & TPB \\
\hline $\begin{array}{l}\text { Honkanen et al. } \\
(2006)\end{array}$ & Norway & 1283 & General & $(47)$ & $52 \%$ & Other \\
\hline $\begin{array}{l}\text { Saher et al. } \\
(2006)\end{array}$ & Finland & 3261 & $\begin{array}{l}85 \% \\
\text { Students }\end{array}$ & $15 \sim 60(24)$ & $74 \%$ & Other \\
\hline $\begin{array}{l}\text { Thøgersen \& } \\
\text { Ölander (2006) }\end{array}$ & Denmark & 1520 & General & $18+$ & - & ETPB \\
\hline $\begin{array}{l}\text { Saba \& Messina } \\
(2003)\end{array}$ & Italy & 947 & General & $18 \sim 60(43)$ & 51.5 & TPB \\
\hline $\begin{array}{l}\text { Tanner \& Kast } \\
(2003)\end{array}$ & Switzerland & 547 & General & $18 \sim 90(47)$ & $68 \%$ & Other \\
\hline Bamberg (2002) & Germany & 320 & $\begin{array}{l}\text { University } \\
\text { students }\end{array}$ & - & - & TPB \\
\hline $\begin{array}{l}\text { Robinson \& } \\
\text { Smith (2002) }\end{array}$ & USA & 547 & General & $18 \sim 61+$ & $65 \%$ & ETPB \\
\hline $\begin{array}{l}\text { Bissonnette \& } \\
\text { Contento (2001) }\end{array}$ & USA & 651 & Adolescents & - & 50.2 & ETPB \\
\hline $\begin{array}{l}\text { Sparks \& } \\
\text { Shepherd (1992) }\end{array}$ & UK & 261 & General & - & - & TRA / TPB \\
\hline
\end{tabular}

TPB = Theory of Planned Behavior; ETPB = Extended Theory of Planned Behavior; TRA = Theory of Reasoned Action; FFM = Five-factor Model of Personality

Table 2. Correlates of intention

\begin{tabular}{|c|c|c|c|c|c|c|c|c|c|c|}
\hline Antecedents & $\mathrm{k}$ & $\mathrm{N}$ & $\mathrm{r}_{\mathrm{cu}}$ & $\mathrm{r}_{\mathrm{cwf}}$ & $\begin{array}{c}95 \% \mathrm{CI} \\
\text { of } \mathrm{r}_{\mathrm{cwf}}\end{array}$ & $\mathrm{r}_{\mathrm{cwr}}$ & $\begin{array}{l}95 \% \mathrm{CI} \\
\text { of } \mathrm{r}_{\mathrm{cwr}}\end{array}$ & Failsafe N & $\begin{array}{c}\text { Failsafe } \\
\text { Ratio } \\
\end{array}$ & Q \\
\hline Health $^{\#}$ & 1 & 222 & $0.25^{* * *}$ & & & & & & & \\
\hline Ethical & 5 & 2964 & $0.44^{* * *}$ & $0.43^{* * *}$ & {$[0.39,0.45]$} & $0.46^{* * *}$ & {$[0.38,0.48]$} & 901.84 & 25.77 & 9.17 \\
\hline Beliefs & 5 & 2355 & $0.46^{* * *}$ & $0.36^{* * *}$ & {$[0.32,0.39]$} & $0.45^{* * *}$ & {$[0.24,0.63]$} & 537.54 & 15.36 & $137.25^{* * *}$ \\
\hline $\mathrm{SN}$ & 10 & 3258 & $0.55^{* * *}$ & $0.53^{* * *}$ & {$[0.50,0.55]$} & $0.55^{* * *}$ & {$[0.47,0.63]$} & 3174.42 & 52.91 & $93.27^{* * *}$ \\
\hline $\mathrm{PN}$ & 5 & 1530 & $0.64^{* * *}$ & $0.60^{* * *}$ & {$[0.57,0.64]$} & $0.63^{* * *}$ & {$[0.53,0.71]$} & 989.00 & 28.26 & $32.30^{* * *}$ \\
\hline $\mathrm{PBC}$ & 9 & 2607 & $0.44^{* * *}$ & $0.43^{* * *}$ & {$[0.40,0.46]$} & $0.44^{* * *}$ & {$[0.36,0.52]$} & 1520.92 & 27.65 & $51.50^{* * *}$ \\
\hline Attitude & 13 & 5710 & $0.62^{* * *}$ & $0.55^{* * *}$ & {$[0.54,0.57]$} & $0.62^{* * *}$ & {$[0.52,0.70]$} & 7721.94 & 102.96 & $336.57^{* * *}$ \\
\hline
\end{tabular}

$\mathrm{K}=$ Number of studies; $\mathrm{N}=$ Number of observations; $\mathrm{r}_{\mathrm{cu}}=$ Corrected unweighted population correlation; $\mathrm{r}_{\mathrm{cwf}}=$ Corrected weighted population correlation based on fixed-effects model; $r_{\mathrm{cwr}}=$ Corrected weighted population correlation based on random-effects model; $\mathrm{Q}=$ Chi-square test; ${ }^{\#}$ Insufficient number of studies for moderator analysis; ${ }^{*} \mathrm{p}<0.05,{ }^{* *} \mathrm{p}<0.01$, $* * * \mathrm{p}<0.001$. 
Table 3. Moderator analyses of the relationships between antecedents and intention

\begin{tabular}{|c|c|c|c|c|c|c|c|c|c|c|}
\hline Antecedents & Moderator & $\mathrm{k}$ & $\mathrm{N}$ & $\mathrm{r}_{\text {cuw }}$ & $r_{\text {cwf }}$ & $\begin{array}{c}95 \% \mathrm{CI} \\
\text { of } \mathrm{r}_{\mathrm{cwf}}\end{array}$ & $\mathrm{r}_{\mathrm{cwr}}$ & $\begin{array}{l}95 \% \mathrm{CI} \\
\text { of } \mathrm{r}_{\mathrm{cur}}\end{array}$ & Q & Z \\
\hline \multirow[t]{6}{*}{ Beliefs } & Europe & 4 & 1808 & $0.53^{* * * \pi}$ & $0.42^{* * *}$ & {$[0.38,0.46]$} & $0.52^{* * *}$ & {$[0.29,0.70]$} & $92.60^{* * *}$ & \\
\hline & Non-Europe & 1 & 547 & $0.12^{* * * \pi}$ & & & & & & \\
\hline & Students or young adults & 1 & 456 & $0.50^{* * *}$ & & & & & & \\
\hline & General & 4 & 1899 & $0.45^{* * *}$ & $0.32^{* * *}$ & {$[0.28,0.36]$} & $0.44^{* * *}$ & {$[0.16,0.66]$} & $121.48^{* * *}$ & \\
\hline & Intention to purchase & 3 & 1147 & $0.54^{* * * *}$ & $0.40^{* * * *}$ & {$[0.35,0.44]$} & $0.54^{* * * *}$ & {$[0.10,0.80]$} & $132.75^{* * \pi}$ & $14.01^{* * *}$ \\
\hline & Intention to consume & 2 & 1208 & $0.32^{* * *}$ & $0.32^{* * *}$ & {$[0.27,0.37]$} & $0.32^{* * *}$ & {$[0.27,0.37]$} & 0.09 & \\
\hline \multirow[t]{6}{*}{$\mathrm{SN}$} & Europe & 8 & 2060 & $0.57^{* * *}$ & $0.56^{* * *}$ & {$[0.53,0.59]$} & $0.57^{* * *}$ & {$[0.46,0.66]$} & $83.47^{* * *}$ & $10.72^{* * *}$ \\
\hline & Non-Europe & 2 & 1198 & $0.46^{* 2 * *}$ & $0.48^{* * *}$ & {$[0.44,0.52]$} & $0.48^{* * *}$ & {$[0.42,0.54]$} & 1.94 & \\
\hline & Students or young adults & 3 & 1427 & $0.49^{* * * 4}$ & $0.50^{* * *}$ & {$[0.46,0.53]$} & $0.50^{* * *}$ & {$[0.46,0.53]$} & 0.60 & $9.90^{* * *}$ \\
\hline & General & 7 & 1831 & $0.58^{* * *}$ & $0.55^{* * *}$ & {$[0.52,0.59]$} & $0.58^{* * *}$ & {$[0.45,0.69]$} & $87.48^{* * * *}$ & \\
\hline & Intention to purchase & 9 & 2997 & $0.58^{* * *}$ & $0.55^{* * *}$ & {$[0.52,0.57]$} & $0.57^{* * *}$ & {$[0.49,0.64]$} & $73.90^{* * *}$ & \\
\hline & Intention to consume & 1 & 261 & $0.32^{* * *}$ & & & & & & \\
\hline \multirow[t]{4}{*}{$\mathrm{PN}$} & Europe & 4 & 879 & $0.66^{* * *}$ & $0.65^{* * *}$ & {$[0.61,0.68]$} & $0.66^{* * *}$ & {$[0.54,0.75]$} & $22.62^{* * *}$ & \\
\hline & Non-Europe & 1 & 651 & $0.54^{* * *}$ & & & & & & \\
\hline & Students or young adults & 1 & 651 & $0.54^{* * * 4}$ & & & & & & \\
\hline & General & 4 & 879 & $0.66^{* * *}$ & $0.65^{* * *}$ & {$[0.61,0.68]$} & $0.66^{* * *}$ & {$[0.54,0.75]$} & $22.62^{* * * *}$ & \\
\hline \multirow[t]{6}{*}{ PBC } & Europe & 8 & 2060 & $0.45^{* * *}$ & $0.45^{* * *}$ & {$[0.41,0.48]$} & $0.45^{* * *}$ & {$[0.35,0.54]$} & $48.01^{* * * *}$ & \\
\hline & Non-Europe & 1 & 547 & $0.37^{* * *}$ & & & & & & \\
\hline & Students or young adults & 2 & 776 & $0.53^{* * *}$ & $0.51^{* * *}$ & {$[0.46,0.56]$} & $0.53^{* * *}$ & {$[0.23,0.74]$} & $24.52^{* * * 4}$ & $8.00^{* * * *}$ \\
\hline & General & 7 & 1831 & $0.41^{* * *}$ & $0.39^{* * *}$ & {$[0.35,0.43]$} & $0.41^{* * *}$ & {$[0.34,0.47]$} & $15.34^{*}$ & \\
\hline & Intention to purchase & 8 & 2346 & $0.45^{* * *+}$ & $0.44^{* * * * 4}$ & {$[0.41,0.47]$} & $0.45^{* * * *}$ & {$[0.36,0.53]$} & 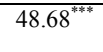 & \\
\hline & Intention to consume & 1 & 261 & $0.35^{* * * *}$ & & & & & & \\
\hline \multirow[t]{8}{*}{ Attitude } & Europe & 11 & 4512 & $0.63^{* * *}$ & $0.55^{* * *}$ & {$[0.53,0.57]$} & $0.63^{* * * *}$ & {$[0.52,0.71]$} & $321.26^{* * *}$ & $4.62^{* * *}$ \\
\hline & Non-Europe & 2 & 1198 & $0.58^{* * *}$ & $0.58^{* * *}$ & {$[0.55,0.62]$} & $0.58^{* * *}$ & {$[0.43,0.70]$} & $12.32^{* * *}$ & \\
\hline & Students or young adults & 3 & 1427 & $0.67^{* * *}$ & $0.67^{* * *}$ & {$[0.64,0.70]$} & $0.67^{* * * *}$ & {$[0.52,0.78]$} & $36.75^{\text {*** }}$ & $6.71^{* * *}$ \\
\hline & General & 10 & 4283 & $0.60^{* * *}$ & $0.51^{* * *}$ & {$[0.49,0.53]$} & $0.60^{* * *}$ & {$[0.49,0.69]$} & $230.53^{* * *}$ & \\
\hline & Intention to purchase & 10 & 3219 & $0.67^{* * *}$ & $0.65^{* * *}$ & {$[0.63,0.67]$} & $0.67^{* * *}$ & {$[0.57,0.75]$} & $172.17^{* * *}$ & $45.30^{* * *}$ \\
\hline & Intention to consume & 3 & 2491 & $0.41^{* * *}$ & $0.41^{* * *}$ & {$[0.37,0.44]$} & $0.41^{* * *}$ & {$[0.38,0.44]$} & 0.31 & \\
\hline & TPB or ETPB & 11 & 4205 & $0.63^{* * *}$ & $0.59^{* * *}$ & {$[0.57,0.61]$} & $0.63^{* * *}$ & {$[0.52,0.71]$} & $261.37^{* * *}$ & $5.06^{* * * *}$ \\
\hline & Others & 2 & 1505 & $0.56^{* * *}$ & $0.45^{* * *}$ & {$[0.41,0.49]$} & $0.56^{* * *}$ & {$[0.21,0.79]$} & $35.27^{* * *}$ & \\
\hline
\end{tabular}

$\mathrm{K}=$ Number of studies; $\mathrm{N}=$ Number of observations; $\mathrm{r}_{\mathrm{cuw}}=$ Corrected unweighted population correlation; $r_{\mathrm{cwf}}=$ Corrected weighted population correlation based on fixed-effects model; $r_{\mathrm{cwr}}=$ Corrected weighted population correlation based on random-effects model; $\mathrm{Q}=\mathrm{Chi}$-square test; $\mathrm{Z}=\mathrm{Z}$ statistic for the critical ratio $\left(\mathrm{Z}_{0.05}=1.96, \mathrm{Z}_{0.01}=2.58, \mathrm{Z}_{0.001}=3.30\right.$; two-tailed test $)$ that indicates whether moderator subgroups are significantly different; $* \mathrm{p}<0.05, * * \mathrm{p}=0.01, * * * \mathrm{p}=0.001$. 
Table 4. Correlates of B-I and A-I after outliers removed

\begin{tabular}{|l|l|l|l|l|l|l|l|l|l|l|}
\hline Antecedents & $\mathrm{k}$ & $\mathrm{N}$ & $\mathrm{r}_{\mathrm{cu}}$ & $\mathrm{r}_{\mathrm{cwf}}$ & $\begin{array}{l}95 \% \mathrm{CI} \\
\text { of } \mathrm{r}_{\mathrm{cwf}}\end{array}$ & $\mathrm{r}_{\mathrm{cwr}}$ & $\begin{array}{l}95 \% \mathrm{CI} \\
\text { of }_{\mathrm{cwr}}\end{array}$ & Failsafe N & Failsafe Ratio & $\mathrm{Q}$ \\
\hline Beliefs & 4 & 1808 & $0.53^{* * *}$ & $0.42^{* * *}$ & {$[0.38,0.46]$} & $0.52^{* * *}$ & {$[0.29,0.70]$} & 459.61 & 15.32 & $92.60^{* * *}$ \\
\hline Attitude & 12 & 4427 & $0.63^{* * *}$ & $0.59^{* * *}$ & {$[0.58,0.61]$} & $0.63^{* * *}$ & {$[0.54,0.71]$} & 6271.78 & 89.60 & $268.15^{* * *}$ \\
\hline
\end{tabular}

$\mathrm{K}=$ Number of studies; $\mathrm{N}=$ Number of observations; $\mathrm{r}_{\mathrm{cu}}=$ Corrected unweighted population correlation; $\mathrm{r}_{\mathrm{cwf}}=$ Corrected weighted population correlation based on fixed-effects model; $r_{\text {cwr }}=$ Corrected weighted population correlation based on random-effects model; $Q=$ Chi-square test; ${ }^{*} \mathrm{p}<0.05,{ }^{*} \mathrm{p}<0.01,{ }^{* * *} \mathrm{p}<0.001$.

Table 5. Correlates of behavior

\begin{tabular}{|l|c|c|c|c|c|c|c|c|c|c|}
\hline Antecedents & $\mathrm{k}$ & $\mathrm{N}$ & $\mathrm{r}_{\mathrm{cu}}$ & $\mathrm{r}_{\mathrm{cwf}}$ & $\begin{array}{c}95 \% \mathrm{CI} \\
\text { of } \mathrm{r}_{\mathrm{cwf}}\end{array}$ & $\mathrm{r}_{\mathrm{cwr}}$ & $\begin{array}{c}95 \% \mathrm{CI} \\
\text { of } \mathrm{r}_{\mathrm{cwr}}\end{array}$ & $\begin{array}{c}\text { Failsafe } \\
\mathrm{N}\end{array}$ & $\begin{array}{c}\text { Failsafe } \\
\text { Ratio }\end{array}$ & Q \\
\hline Health $^{\#}$ & 1 & 547 & $0.47^{* * *}$ & & & & & & & \\
\hline Ethical $^{\#}$ & 1 & 547 & $0.66^{* * *}$ & & & & & & & \\
\hline Beliefs $^{\#}$ & 3 & 1557 & $0.40^{* * *}$ & $0.36^{* * *}$ & {$[0.32,0.41]$} & $0.38^{* * *}$ & {$[0.30,0.45]$} & 197.50 & 7.90 & 4.54 \\
\hline SN $^{\#}$ & 3 & 1903 & $0.53^{* * *}$ & $0.76^{* * *}$ & {$[0.74,0.77]$} & $0.53^{* * *}$ & {$[-0.15,0.87]$} & 552.64 & 22.11 & $263.66^{* * *}$ \\
\hline PN $^{\#}$ & 3 & 2130 & $0.70^{* * *}$ & $0.82^{* * *}$ & {$[0.81,0.83]$} & $0.70^{* * *}$ & {$[0.14,0.92]$} & 919.09 & 36.76 & $366.79^{* * *}$ \\
\hline PBC $^{\text {Attitude }}$ & 4 & 2450 & $0.38^{* * *}$ & $0.32^{* * *}$ & {$[0.29,0.36]$} & $0.38^{* * *}$ & {$[0.23,0.50]$} & 344.71 & 11.49 & $31.88^{* * *}$ \\
\hline Intention $^{\#}$ & 3 & 2787 & $0.58^{* * *}$ & $0.69^{* * *}$ & {$[0.67,0.71]$} & $0.58^{* * *}$ & {$[0.05,0.85]$} & 952.24 & 38.09 & $459.75^{* * *}$ \\
\hline
\end{tabular}

$\mathrm{K}=$ Number of studies; $\mathrm{N}=$ Number of observations; $\mathrm{r}_{\mathrm{cu}}=$ Corrected unweighted population correlation; $\mathrm{r}_{\mathrm{cwf}}=$ Corrected weighted population correlation based on fixed-effects model; $r_{c w r}=$ Corrected weighted population correlation based on random-effects model; Q $=$ Chi-square test; ${ }^{\#}$ Insufficient number of studies for moderator analysis; ${ }^{*} \mathrm{p}<0.05,{ }^{* *} \mathrm{p}<0.01$, $* * * \mathrm{p}<0.001$. 
Table 6. Moderator analyses of the relationships between antecedents and behavior

\begin{tabular}{|c|c|c|c|c|c|c|c|c|c|c|}
\hline Antecedents & Moderator & $\mathrm{k}$ & $\mathrm{N}$ & $r_{\text {cuw }}$ & $\mathrm{r}_{\mathrm{cwf}}$ & $\begin{array}{c}95 \% \mathrm{CI} \\
\text { of } \mathrm{r}_{\mathrm{cwf}}\end{array}$ & $r_{\mathrm{cwr}}$ & $\begin{array}{c}95 \% \mathrm{CI} \\
\text { of } \mathrm{r}_{\mathrm{cwr}}\end{array}$ & Q & $\mathrm{Z}$ \\
\hline \multirow[t]{6}{*}{$\mathrm{SN}$} & $\begin{array}{l}\text { Students or } \\
\text { young adults }\end{array}$ & 1 & 320 & $0.21^{* * *}$ & & & & & & \\
\hline & General & 2 & 1583 & $0.65^{* * *}$ & $0.81^{* * *}$ & {$[0.80,0.83]$} & $0.66^{* * *}$ & {$[0.02,0.91]$} & $35.38^{* * *}$ & \\
\hline & $\begin{array}{l}\text { Self-reported } \\
\text { purchase }\end{array}$ & 2 & 1583 & $0.65^{* * *}$ & $0.81^{* * *}$ & {$[0.80,0.83]$} & $0.66^{* * *}$ & {$[0.02,0.91]$} & $35.38^{* * *}$ & \\
\hline & $\begin{array}{l}\text { Observed } \\
\text { purchase }\end{array}$ & 1 & 320 & $0.21^{* * *}$ & & & & & & \\
\hline & $\begin{array}{l}\text { TPB or } \\
\text { ETPB }\end{array}$ & 2 & 1840 & $0.60^{* * *}$ & $0.76^{* * *}$ & {$[0.74,0.78]$} & $0.60^{* * *}$ & {$[-0.24,0.93]$} & $241.54^{* * *}$ & \\
\hline & Others & 1 & 63 & $0.37^{* * *}$ & & & & & & \\
\hline \multirow[t]{2}{*}{$\mathrm{PN}$} & $\begin{array}{l}\text { TPB or } \\
\text { ETPB }\end{array}$ & 1 & 1520 & $0.89^{* * *}$ & & & & & & \\
\hline & Others & 2 & 610 & $0.53^{* * *}$ & $0.46^{* * *}$ & {$[0.40,0.53]$} & $0.50^{* * *}$ & {$[0.34,0.64]$} & 2.43 & \\
\hline \multirow[t]{6}{*}{ PBC } & $\begin{array}{l}\text { Students or } \\
\text { young adults }\end{array}$ & 1 & 320 & $0.38^{* * *}$ & & & & & & \\
\hline & General & 3 & 2130 & $0.38^{* * *}$ & $0.31^{* * *}$ & {$[0.27,0.35]$} & $0.37^{* * *}$ & {$[0.17,0.54]$} & $30.18^{* * *}$ & \\
\hline & $\begin{array}{l}\text { Self-reported } \\
\text { purchase }\end{array}$ & 3 & 2130 & $0.38^{* * *}$ & $0.31^{* * *}$ & {$[0.27,0.35]$} & $0.37^{* * *}$ & {$[0.17,0.54]$} & $30.18^{* * *}$ & \\
\hline & $\begin{array}{l}\text { Observed } \\
\text { purchase }\end{array}$ & 1 & 320 & $0.38^{* * *}$ & & & & & & \\
\hline & $\begin{array}{l}\text { TPB or } \\
\text { ETPB }\end{array}$ & 2 & 1840 & $0.31^{* * *}$ & $0.27^{* * *}$ & {$[0.23,0.31]$} & $0.31^{* * *}$ & {$[0.17,0.44]$} & $6.14^{*}$ & $15.75^{* * *}$ \\
\hline & Others & 2 & 610 & $0.44^{* * *}$ & $0.47^{* * *}$ & {$[0.41,0.53]$} & $0.47^{* * *}$ & {$[0.41,0.53]$} & 0.50 & \\
\hline \multirow[t]{4}{*}{ Attitude } & $\begin{array}{l}\text { Students or } \\
\text { young adults }\end{array}$ & 1 & 320 & $0.30^{* * *}$ & & & & & & \\
\hline & General & 2 & 2467 & $0.68^{* * *}$ & $0.73^{* * *}$ & {$[0.71,0.75]$} & $0.68^{* * *}$ & {$[0.07,0.92]$} & $352.79^{* * *}$ & \\
\hline & $\begin{array}{l}\text { Self-reported } \\
\text { purchase }\end{array}$ & 2 & 2467 & $0.68^{* * *}$ & $0.73^{* * *}$ & {$[0.71,0.75]$} & $0.68^{* * *}$ & {$[0.07,0.92]$} & $352.79^{* * *}$ & \\
\hline & $\begin{array}{l}\text { Observed } \\
\text { purchase }\end{array}$ & 1 & 320 & $0.30^{* * *}$ & & & & & & \\
\hline \multirow[t]{4}{*}{ Intention } & $\begin{array}{l}\text { Students or } \\
\text { young adults }\end{array}$ & 2 & 971 & $0.42^{* * *}$ & $0.43^{* * *}$ & {$[0.37,0.48]$} & $0.43^{* * *}$ & {$[0.38,0.47]$} & 0.85 & \\
\hline & General & 1 & 947 & $0.52^{* * *}$ & & & & & & \\
\hline & $\begin{array}{l}\text { Self-reported } \\
\text { purchase }\end{array}$ & 2 & 1598 & $0.48^{* * *}$ & $0.49^{* * *}$ & {$[0.45,0.53]$} & $0.48^{* * *}$ & {$[0.41,0.56]$} & $3.88^{*}$ & \\
\hline & $\begin{array}{l}\text { Observed } \\
\text { purchase }\end{array}$ & 1 & 320 & $0.39^{* * *}$ & & & & & & \\
\hline
\end{tabular}

$\mathrm{K}=$ Number of studies; $\mathrm{N}=$ Number of observations; $\mathrm{r}_{\text {cuw }}=$ Corrected unweighted population correlation; $\mathrm{r}_{\text {cwf }}=$ Corrected weighted population correlation based on fixed-effects model; $\mathrm{r}_{\mathrm{cwr}}=$ Corrected weighted population correlation based on random-effects model; $Q=$ Chi-square test; $Z=Z$ statistic for the critical ratio $\left(Z_{0.05}=1.96, Z_{0.01}=2.58, Z_{0.001}=3.30\right.$; two-tailed test) that indicates whether moderator subgroups are significantly different; ${ }^{*} p<0.05,{ }^{* *} p=0.01$, $* * * \mathrm{p}=0.001$. 
Table 7. Correlates of SN-B, PN-B, PBC-B, and A-B after outliers removed

\begin{tabular}{|l|c|c|c|c|c|c|c|c|c|c|}
\hline Antecedents & $\mathrm{k}$ & $\mathrm{N}$ & $\mathrm{r}_{\mathrm{cu}}$ & $\mathrm{r}_{\mathrm{cwf}}$ & $\begin{array}{c}95 \% \mathrm{CI} \\
\text { of } \mathrm{r}_{\mathrm{cwf}}\end{array}$ & $\mathrm{r}_{\mathrm{cwr}}$ & $\begin{array}{c}95 \% \text { CI } \\
\text { of } \mathrm{r}_{\mathrm{cwr}}\end{array}$ & $\begin{array}{c}\text { Failsafe } \\
\mathrm{N}\end{array}$ & $\begin{array}{c}\text { Failsafe } \\
\text { Ratio }\end{array}$ & Q \\
\hline $\mathrm{SN}$ & 2 & 383 & $0.29^{* * *}$ & $0.24^{* * *}$ & {$[0.14,0.33]$} & $0.25^{* * *}$ & {$[0.10,0.39]$} & 14.28 & 0.71 & 1.58 \\
\hline PN & 2 & 610 & $0.53^{* * *}$ & $0.46^{* * *}$ & {$[0.40,0.53]$} & $0.50^{* * *}$ & {$[0.34,0.64]$} & 83.98 & 4.20 & 2.43 \\
\hline PBC & 3 & 930 & $0.42^{* * *}$ & $0.44^{* * *}$ & {$[0.39,0.49]$} & $0.43^{* * *}$ & {$[0.36,0.50]$} & 163.10 & 6.52 & 2.97 \\
\hline Attitude & 2 & 1267 & $0.36^{* * *}$ & $0.39^{* * *}$ & {$[0.34,0.43]$} & $0.36^{* * *}$ & {$[0.24,0.47]$} & 118.97 & 5.95 & $4.46^{*}$ \\
\hline
\end{tabular}

$\mathrm{K}=$ Number of studies; $\mathrm{N}=$ Number of observations; $\mathrm{r}_{\mathrm{cu}}=$ Corrected unweighted population correlation; $\mathrm{r}_{\mathrm{cwf}}$ $=$ Corrected weighted population correlation based on fixed-effects model; $r_{\mathrm{cwr}}=$ Corrected weighted population correlation based on random-effects model; $\mathrm{Q}=$ Chi-square test; ${ }^{*} \mathrm{p}<0.05,{ }^{* *} \mathrm{p}<0.01,{ }^{* * *} \mathrm{p}<0.001$.

Table 8. Total sample size and number of independent correlations (between parentheses) included in each cell without outliers

\begin{tabular}{|l|l|l|l|l|l|l|l|l|}
\hline & \multicolumn{1}{|c|}{1} & \multicolumn{1}{|c|}{2} & \multicolumn{1}{c|}{3} & \multicolumn{1}{c|}{4} & \multicolumn{1}{c|}{5} & \multicolumn{1}{c|}{6} & 7 \\
\hline 1. Health & & & & & & & & \\
\hline 2. Ethical & $1239(3)$ & & & & & & & \\
\hline 3. Beliefs & $547(1)$ & $1355(3)$ & & & & & & \\
\hline 4. SN & $-\#$ & $808(2)$ & $1015(4)$ & & & & & \\
\hline 5. PN & $547(1)$ & $547(1)$ & $610(2)$ & $942(5)$ & & & & \\
\hline 6. Attitude & $692(2)$ & $2783(5)$ & $2550(5)$ & $3464(8)$ & $672(3)$ & & & \\
\hline 7. PBC & $547(1)$ & $1094(2)$ & $1418(4)$ & $2070(8)$ & $2462(6)$ & $2151(8)$ & & \\
\hline 8. Intention & $222(1)$ & $2964(5)$ & $1808(4)$ & $3258(10)$ & $1530(5)$ & $4427(12)$ & $2607(9)$ & \\
\hline 9. Behavior & $547(1)$ & $547(1)$ & $1557(3)$ & $383(2)$ & $610(2)$ & $1267(2)$ & $930(3)$ & $1918(3)$ \\
\hline
\end{tabular}

\# No pooled correlation.

Table 9. Meta-Analytic Correlation Values between the constructs under fixed-effects (upper triangular matrix) and random-effects assumption (lower triangular matrix) without outliers

\begin{tabular}{|l|c|c|c|c|c|c|c|c|c|}
\hline Construct & 1 & 2 & 3 & 4 & 5 & 6 & 7 & 8 & 9 \\
\hline 1. Health & - & 0.59 & $0.31^{\#}$ & - & $0.71^{\#}$ & 0.68 & $0.39^{\#}$ & $0.25^{\#}$ & $0.47^{\#}$ \\
\hline 2. Ethical & 0.56 & - & 0.40 & 0.50 & $0.76^{\#}$ & 0.54 & 0.43 & 0.42 & $0.66^{\#}$ \\
\hline 3. Beliefs & $0.31^{\#}$ & 0.40 & - & 0.33 & 0.39 & 0.61 & 0.26 & 0.42 & 0.36 \\
\hline 4. SN & - & 0.46 & 0.33 & - & 0.65 & 0.63 & 0.35 & 0.53 & 0.24 \\
\hline 5. PN & $0.71^{\#}$ & $0.76^{\#}$ & 0.39 & 0.62 & - & 0.73 & 0.23 & 0.60 & 0.46 \\
\hline 6. Attitude & 0.61 & 0.56 & 0.60 & 0.61 & 0.74 & - & 0.33 & 0.59 & 0.39 \\
\hline 7. PBC & $0.39^{\#}$ & 0.77 & 0.22 & 0.34 & 0.28 & 0.34 & - & 0.43 & 0.44 \\
\hline 8. Intention & $0.25^{\#}$ & 0.43 & 0.52 & 0.55 & 0.63 & 0.63 & 0.44 & - & 0.47 \\
\hline 9. Behavior & $0.47^{\#}$ & $0.66^{\#}$ & 0.38 & 0.25 & 0.50 & 0.36 & 0.43 & 0.46 & - \\
\hline
\end{tabular}

* Adjusted correlation based on only one study 
Table 10. The 95\%-confidence intervals of the correlations calculated under fixed-effects assumption (upper triangular matrix) and random-effects assumption (lower triangular matrix) without outliers

\begin{tabular}{|c|c|c|c|c|c|c|c|c|c|}
\hline Construct & 1 & 2 & 3 & 4 & 5 & 6 & 7 & 8 & 9 \\
\hline 1. Health & - & $\begin{array}{l}{[0.56} \\
0.63]\end{array}$ & - $^{\#}$ & - $^{\#}$ & — $^{\#}$ & $\begin{array}{l}{[0.64} \\
0.72]\end{array}$ & — & — $^{\#}$ & - $^{\#}$ \\
\hline 2. Ethical & $\begin{array}{l}{[0.34} \\
0.72]\end{array}$ & - & $\begin{array}{l}{[0.36} \\
0.45]\end{array}$ & $\begin{array}{l}{[0.44,} \\
0.55]\end{array}$ & - & $\begin{array}{l}{[0.52} \\
0.57]\end{array}$ & $\begin{array}{l}{[0.38,} \\
0.48]\end{array}$ & $\begin{array}{l}{[0.39} \\
0.45]\end{array}$ & - \\
\hline 3. Beliefs & \# & $\begin{array}{l}{[0.34} \\
0.46]\end{array}$ & - & $\begin{array}{l}0.27 \\
0.38]\end{array}$ & $\begin{array}{l}0.32, \\
0.46]\end{array}$ & $\begin{array}{l}{[0.59} \\
0.64]\end{array}$ & $\begin{array}{l}{[0.21} \\
0.31]\end{array}$ & $\begin{array}{l}0.38, \\
0.46]\end{array}$ & $\begin{array}{l}{[0.32,} \\
0.41]\end{array}$ \\
\hline 4. $\mathrm{SN}$ & \# & $\begin{array}{l}{[0.19} \\
0.66]\end{array}$ & $\begin{array}{l}{[0.24} \\
0.42]\end{array}$ & - & $\begin{array}{l}{[0.61,} \\
0.69]\end{array}$ & $\begin{array}{l}{[0.61,} \\
0.65]\end{array}$ & $\begin{array}{l}{[0.31,} \\
0.38]\end{array}$ & $\begin{array}{l}{[0.50} \\
0.55]\end{array}$ & $\begin{array}{l}{[0.14,} \\
0.33]\end{array}$ \\
\hline 5. PN & \# & - & $\begin{array}{l}0.32, \\
0.46]\end{array}$ & $\begin{array}{l}{[0.44,} \\
0.75]\end{array}$ & - & $\begin{array}{l}0.70 \\
0.77]\end{array}$ & $\begin{array}{l}{[0.19,} \\
0.27]\end{array}$ & $\begin{array}{l}{[0.57,} \\
0.64]\end{array}$ & $\begin{array}{l}0.40, \\
0.53]\end{array}$ \\
\hline 6. Attitude & $\begin{array}{c}{[0.05} \\
0.88]\end{array}$ & $\begin{array}{l}{[0.48} \\
0.64]\end{array}$ & $\begin{array}{l}{[0.49} \\
0.69]\end{array}$ & $\begin{array}{l}{[0.50} \\
0.70]\end{array}$ & $\begin{array}{l}{[0.63} \\
0.81]\end{array}$ & - & $\begin{array}{l}{[0.29} \\
0.37]\end{array}$ & $\begin{array}{l}{[0.58} \\
0.61]\end{array}$ & $\begin{array}{l}{[0.34,} \\
0.43]\end{array}$ \\
\hline 7. $\mathrm{PBC}$ & \# & $\begin{array}{l}0.55 \\
0.89]\end{array}$ & $\begin{array}{l}{[0.01,} \\
0.42]\end{array}$ & $\begin{array}{l}0.22, \\
0.45]\end{array}$ & $\begin{array}{l}0.17 \\
0.38]\end{array}$ & $\begin{array}{l}0.21, \\
0.46]\end{array}$ & - & $\begin{array}{l}0.40, \\
0.46]\end{array}$ & $\begin{array}{l}0.39, \\
0.49]\end{array}$ \\
\hline 8. Intention & - & $\begin{array}{l}{[0.38} \\
0.48]\end{array}$ & $\begin{array}{l}{[0.29} \\
0.70]\end{array}$ & $\begin{array}{l}{[0.47} \\
0.63]\end{array}$ & $\begin{array}{l}{[0.53} \\
0.71]\end{array}$ & $\begin{array}{l}{[0.54} \\
0.71]\end{array}$ & $\begin{array}{l}{[0.36} \\
0.52]\end{array}$ & - & $\begin{array}{l}{[0.44,} \\
0.51]\end{array}$ \\
\hline 9. Behavior & - & -\# & $\begin{array}{l}{[0.30} \\
0.45]\end{array}$ & $\begin{array}{l}0.10 \\
0.39]\end{array}$ & $\begin{array}{l}{[0.34} \\
0.64]\end{array}$ & $\begin{array}{l}{[0.24} \\
0.47]\end{array}$ & $\begin{array}{l}{[0.36,} \\
0.50]\end{array}$ & $\begin{array}{l}0.38, \\
0.53]\end{array}$ & - \\
\hline
\end{tabular}

${ }^{*}$ No pooled correlation.

Table 11. Summary of fit indices of TPB and ETPB models

\begin{tabular}{|c|c|c|c|c|c|c|c|c|}
\hline Model & $\chi^{2}$ & df & GFI & NFI & CFI & SRMR & RMSEA & 90\% CI of RMSEA \\
\hline TPB & 18.46 & 2 & 0.99 & 0.99 & 0.99 & 0.016 & 0.076 & $0.047-0.11$ \\
\hline ETPB & 201.63 & 4 & 0.95 & 0.96 & 0.96 & 0.058 & 0.19 & $0.17-0.22$ \\
\hline
\end{tabular}




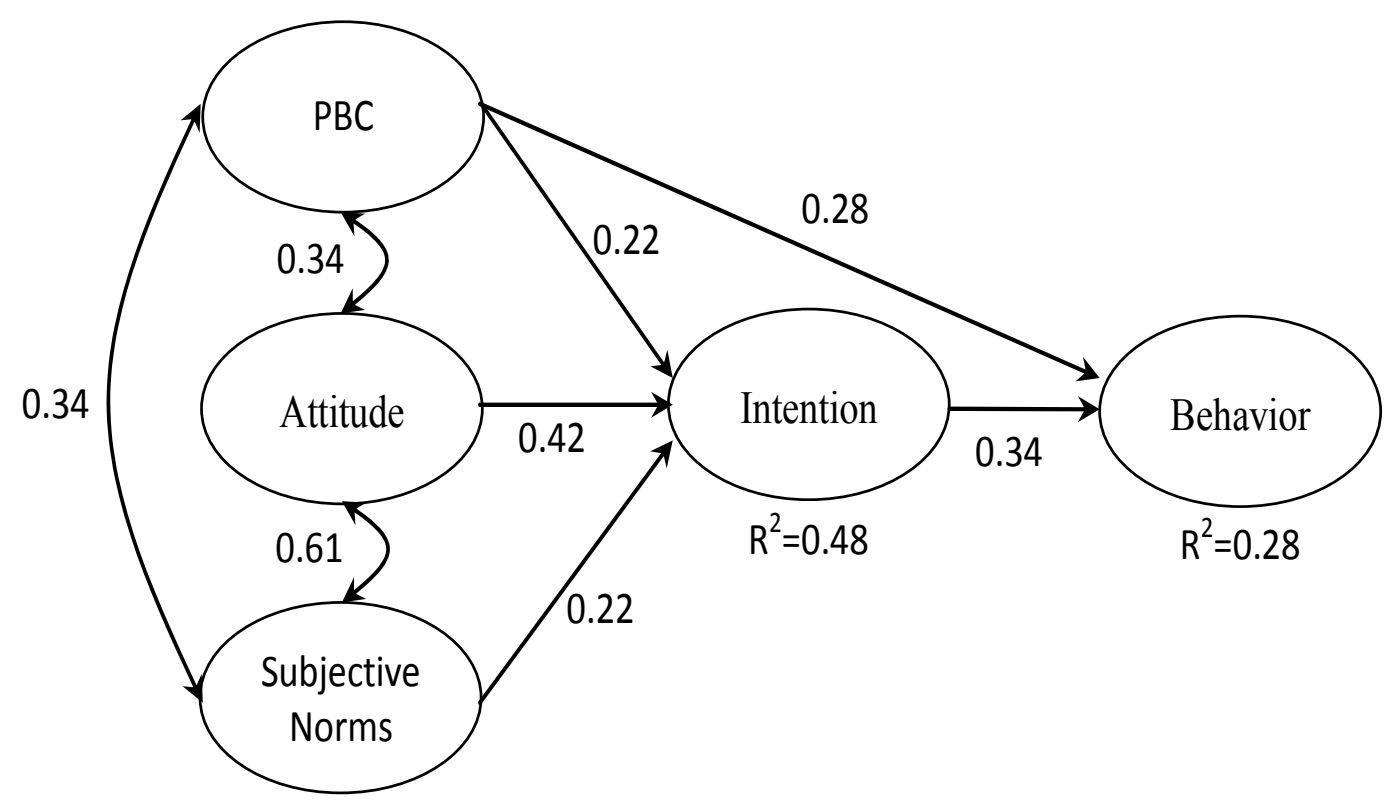

Figure 1. Results of the Meta-Analytic Structural Equations Modeling for the TPB

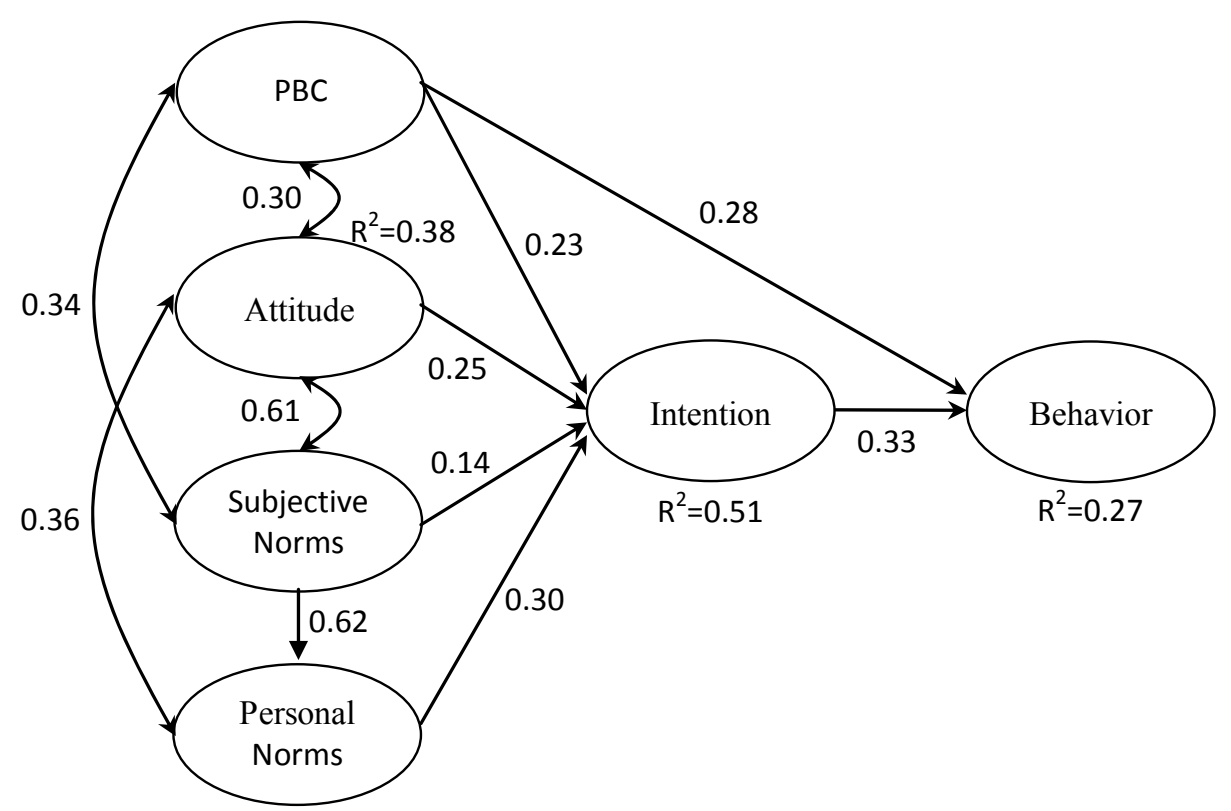

Figure 2. Results of the Meta-Analytic Structural Equations Modeling for the ETPB 